\title{
The Mutual Effect of Irrigation Intervals and Weed Control for Enhancing Yield and Productivity of Irrigation Water for Two Rice Cultivars
}

\author{
El-Ghandor ${ }^{1}$, A. M. A.; M. A. Mahmoud ${ }^{2}$ and A. M. Khozimy ${ }^{3 *}$ \\ ${ }^{1}$ Rice Res. Dep., Field Crops Res. Inst., ARC, Giza, Egypt \\ ${ }^{2}$ Water Requirements and Field Irrigation Dept., Soils, Water and Environment Research Institute, ARC, Giza, Egypt \\ ${ }^{3}$ Plant Protection Dep., Faculty of Agric., Damanhour University, Egypt
}

Received: $17 / 02 / 2020$

\begin{abstract}
Two field experiments were conducted through 2018 and 2019 summer growing seasons at Sakha Agricultural Research Station, Kafrelsheikh, Egypt to study effect of irrigation intervals and weed control for maximizing yield and productivity of irrigation water on Sakha 107 and Giza 179 rice cultivars. A strip split-plot experimental design, with three replications was used in both seasons. Three irrigation intervals i.e; irrigation every three days, every six days and every nine days were assigned in horizontal plots. Two rice cultivars viz; Sakha 107 and Giza 179 were randomly distributed in vertical plots. Six weed control treatments i.e., Saturn 50\% EC (thiobencarb), Ronstar 25\% EC (oxadiazon), Saturn followed by ( $f b$ ) Granite 24\% SC (penoxsulam), Ronstar $f b$ Granite, hand weeding and weedy check were allocated in the sub-plots. The results of both seasons showed that, irrigation every 3-days recorded the lowest dry weights of $E$ crus-galli and total weeds while, irrigation every 9-days recorded the lowest dry weights of $A$. baccifera and $C$. difformis. The highest rice dry weight, number of panicle $\mathrm{m}^{-2}$, number of filled grain panicle $^{-1}$, panicle weight and rice grain yield were recorded by irrigation every 3-days as compared to 6 and 9 days. Rice cultivar Giza 179 exceeded Sakha 107, it recorded the lowest dry weights of A. baccifera, E crus-galli and total weeds in addition, increased number of panicle $\mathrm{m}^{-2}$, number of filled grain panicle ${ }^{-1}$ and rice grain yield while, the highest panicle weight was recorded by Sakha 107. Application of Ronstar $f b$ Granite at recommended doses achieved the best weed management, the highest weed control efficiency (\%), rice grain yield and its attributes as well as productivity of irrigation water (PIW) compared to other treatments. The amount of irrigation water applied was decreased by $15 \%$ and $31 \%$ for six and nine days compared to three days, while productivity of irrigation water was taken the descending order six $>$ three $>$ nine days. To achieve the best weed control efficiency (\%), yield and its attributes as well as save irrigation water and promote PIW, it could be apply irrigation every 6-days with Giza $179 \mathrm{cv}$ treated by Ronstar $f b$ Granite at recommended doses. But in case of water shortage, it could be apply irrigation every 9days with Sakha $107 \mathrm{cv}$ treated by Ronstar $f b$ Granite at recommended doses.
\end{abstract}

Keywords: Rice yield, Irrigation, Weeds, Weed control and Productivity of irrigation water

\section{INTRODUCTION}

Rice (Oryza sativa L.) is one of the most essential cereal crops not only in Egypt but also overall the world, it is considered the main food for about the half of world population, contributing about $20 \%$ of cereal consumption. Moreover, it is the principle food of the majority of Egyptians. According to FAOSTAT the harvested rice area in Egypt was 685.908 hectares (1.632.461 feddan) in 2017 with total production of 6.380 .000 million tons with an average productivity $9.30 \mathrm{t} \mathrm{ha}^{-1}\left(3.908 \mathrm{t} \mathrm{fed}^{-1}\right)$. In Egypt, water resources are limited, however there is a rapidly population increasing. So, maximizing rice productivity is a main strategy to cope with the continuous increasing of rice consumers needs. To increase rice yield in the future, management strategies that facilitate continued production of rice using less water must be developed (Gealy et al., 2014) Scheduling irrigation through applying irrigation intervals is one of the most effective and applicable on-farm practices to rationalize irrigation water and enhancing rice productivity. Alternate wetting and drying in rice fields is one of onfarm practices that saved about $15 \%$ - 50\% of applied water (Naresh et al., 2014) and enhanced productivity of irrigation water by $5-35 \%$ compared to traditional continuous flooding (Romeo et al., 2004). There was no significant difference between continuous flooding and alternate wetting and drying on rice grain yield

\footnotetext{
Corresponding author e-mail: dralaa1977@yahoo.com

(Liang et al., 2016). Number of productive tillers and rice grain yield were significantly recorded higher under alternate wetting and drying compared to continuous flooding (Norton et al., 2017). On the other hand, there was significant reduction of rice grain yield when apply severe alternate wetting and drying compared to continuous flooded (Kumar et al., 2017). But the saved amount of irrigation water and water productivity increased when using alternate wetting and drying (kar et al., 2017). Maintaining the soil moisture content at saturation and then reflooding was the optimal water management practice for growing rice in the swelling clay soil, achieved significant increase in the dry mass production (Alhaj et al., 2019). There was no significant differences of rice grain yield between irrigation intervals every 4 and 6 days (Mahmoud, 2015). Rice varieties are another important factor to define the suitable irrigation intervals, because they show significant variations in physiological response to water stress (Abbasi and Sepaskhah, 2011). The growth of rice cultivars is likely to show different response under water stress conditions and the amounts of irrigation water applied. Some rice cultivars can maintain its water uptake under lower soil water content, so these cultivars may be become important under water shortage to produce large amounts of grain yield (Kato et al., 2006). Weeds are one of the most important limiting factors in rice 
production, as they contribute to great yield losses, if no weed control measures were applied. Weeds cause great reduction in crop yield because of its growth faster and absorption the available water and nutrients earlier than rice plant and this affect the growth and yield of rice (Islam et al., 2015). Furthermore, any delay in weed control will lead to increase weed biomass which has a negative correlation with yield (Manhanas et al., 2012). Weeds are the considerable problem under aerobic rice system whereas, the aerobic soil dry-tillage and alternate wetting and drying conditions are conducive to the germination and growth of weeds causing grain yield losses about 30 to 98\% (Ramana et al., 2014). Under aerobic soil conditions, weed diversity is much higher compared to that under saturated or flooded conditions (Anwar et al., 2010). So, successful of aerobic rice culture will largely depend on effective weed control. In rice cultivation systems, weed species has different response to changing water regimes, Bajavathinnan et al. (2011) found that broad-leaves and sedges grow rapidly when soil was submerged with water, whereas grassy weeds were favored unsaturated conditions. However, wide irrigation intervals were given a great chance of weed seeds germination and growth to compete with the crop on water, nutrients, place and light resulting in undesirable growth conditions for rice, so a great economic loss of rice yield were happened (Abd El-Naby et al., 2017). In this concern, Abd El-Naby and Mahmoud (2018) found irrigation interval every 3 days was the best treatment in weed management, rice dry weight, number of panicles $/ \mathrm{m}^{2}$, number of filled grain/panicle and grain yield. While irrigation every 6 days and 9 days saved about $20.7 \%$ and $29.9 \%$ of irrigation water compared to irrigation every 3 days. Weed management through hand weeding is effective to weed control but it is very difficult, time consuming, uneconomical and expensive to control of weeds. Therefore, herbicides can be used to replace manual weeding (Munda et al., 2017). Chemical weed control method is becoming popular among the farmers because it is the most efficient means, easy to apply, economically available method for controlling different weed species at the same time, it reduce weeds competition, allowing better growth and high grain production of rice (Bajavathinnan et al., 2011). The integration between irrigation intervals and weed management is very important issue for rice production and taken more and more attention nowadays. So, the present work aimed to enhance productivity of irrigation water and rice yield using irrigation intervals and weed control treatments for two rice cultivars.

\section{MATERIALS AND METHODS}

\section{Site Experiment:}

Two field experiments were conducted through 2018 and 2019 summer growing seasons at Sakha Agricultural Research Station, Kafrelsheikh, Egypt to study the effect of irrigation intervals and weed management on rice and weeds under transplanted rice method.

The weather data were taken from Sakha agrometeorological station during 2018 and 2019 seasons as shown in Table (1).

Table (1): Sakha agro-meteorological data, (31 $07^{\prime} \mathrm{N}$ Latitude, $30^{\circ} 05^{\prime}$ E Longitude), during 2018 and 2019 seasons

\begin{tabular}{|c|c|c|c|c|c|c|c|c|c|}
\hline \multirow{2}{*}{ Season } & \multirow{2}{*}{ Months } & \multicolumn{3}{|c|}{ Air temperature } & \multicolumn{3}{|c|}{ Relative humidity } & \multirow{2}{*}{$\frac{\text { Wind speed }}{\text { Mean }\left(\mathrm{km} \mathrm{d}^{-1}\right)}$} & \multirow{2}{*}{$\begin{array}{l}\text { Pan evaporation } \\
\text { Mean }\left(\mathrm{mm} \mathrm{d}^{-1}\right)\end{array}$} \\
\hline & & $\operatorname{Max} .{ }^{\circ} \mathrm{C}$ & Min. ${ }^{\circ} \mathrm{C}$ & $\operatorname{Mean}^{\circ} \mathrm{C}$ & Max. \% & Min. \% & Mean \% & & \\
\hline \multirow{5}{*}{2018} & May & 31.2 & 23.8 & 27.5 & 75.6 & 43.9 & 35.8 & 95.8 & 6.33 \\
\hline & June & 32.6 & 25.3 & 29.0 & 75.5 & 48.0 & 61.8 & 98.6 & 7.71 \\
\hline & July & 34.2 & 25.4 & 29.8 & 82.6 & 51.0 & 66.8 & 89.5 & 7.37 \\
\hline & Aug. & 33.9 & 25.2 & 29.6 & 82.4 & 51.8 & 67.1 & 76.0 & 6.42 \\
\hline & Sept. & 32.8 & 23.5 & 28.2 & 83.1 & 48.3 & 65.7 & 68.7 & 4.98 \\
\hline \multirow{5}{*}{2019} & May & 31.9 & 25.4 & 28.7 & 76.4 & 37.9 & 57.2 & 68.4 & 6.83 \\
\hline & June & 33.0 & 28.0 & 30.5 & 81.5 & 50.0 & 65.8 & 103.0 & 8.46 \\
\hline & July & 33.5 & 28.4 & 31.0 & 85.2 & 54.4 & 69.8 & 83.8 & 8.08 \\
\hline & Aug. & 34.2 & 28.9 & 31.6 & 89.7 & 55.6 & 72.7 & 68.7 & 6.82 \\
\hline & Sept. & 32.4 & 27.9 & 30.2 & 83.4 & 52.9 & 68.2 & 76.9 & 5.90 \\
\hline
\end{tabular}

Some soil properties of the experiments site were determined before cultivation. Soil chemical properties were determined according to Page et al. (1982). Soil physical properties i.e. particle-size distribution, bulk density, total porosity, field capacity and permanent wilting point were determined according to Klute (1986). The mean values of the two growing seasons as shown in Table (2). 
Table (2): Some soil physical and chemical properties of the experimental site as mean values of the two growth seasons

\begin{tabular}{|c|c|c|c|c|c|c|c|c|c|c|}
\hline $\begin{array}{l}\text { Soil depth } \\
\text { (cm) }\end{array}$ & $\begin{array}{c}\text { Field } \\
\text { capacity } \\
(\%)\end{array}$ & $\begin{array}{c}\text { Wilting } \\
\text { point } \\
(\%)\end{array}$ & $\begin{array}{l}\text { Bulk density } \\
\quad\left(\mathrm{Mg} \mathrm{m}^{-3}\right)\end{array}$ & $\begin{array}{c}\text { Total } \\
\text { porosity }(\%)\end{array}$ & $\begin{array}{c}\text { Sand } \\
(\%)\end{array}$ & $\begin{array}{l}\text { Silt } \\
(\%)\end{array}$ & $\begin{array}{l}\text { Clay } \\
(\%)\end{array}$ & $\begin{array}{c}\text { Texture } \\
\text { class }\end{array}$ & $\begin{array}{c}E C_{e} \\
\left(d S ~ m^{-1}\right)\end{array}$ & pH \\
\hline $0-15$ & 47.12 & 26.28 & 1.19 & 55.09 & 20.79 & 25.01 & 54.20 & Clayey & 1.93 & 7.90 \\
\hline $15-30$ & 42.31 & 21.63 & 1.27 & 52.07 & 22.06 & 26.92 & 51.02 & Clayey & 2.51 & 8.03 \\
\hline $30-45$ & 39.89 & 20.97 & 1.40 & 47.17 & 21.85 & 27.44 & 50.71 & Clayey & 2.96 & 8.26 \\
\hline $45-60$ & 39.54 & 21.46 & 1.46 & 44.90 & 21.72 & 27.03 & 51.25 & Clayey & 3.70 & 8.53 \\
\hline Mean & 42.22 & 22.59 & 1.33 & 49.81 & 21.60 & 26.60 & 51.80 & Clay & 2.78 & \\
\hline
\end{tabular}

Experimental design and treatments:

A strip split-plot design, with three replications was used in both seasons. The horizontal plots were devoted to three irrigation intervals. Vertical plots were assigned to two rice cultivars (cv), while weed control treatments were distributed in sub-plots in both seasons. The two rice cultivars were transplanting on $3^{\text {rd }}$ and $5^{\text {th }}$ of May in 2018 and 2019 seasons respectively. Pre-germinated seeds were broadcasted in the presence of water after puddling the nursery. 25days old plants were transplanted at 2-3 seedlings per hill. Agricultural practices were applied as recommended in transplanted rice. The studies treatments as following:

\section{A-Irrigation intervals:}

1- Three days (3-days).

2- Six days (6-days).

3- Nine days (9-days).

\section{B-Rice cultivars (cv):}

1- Sakha 107.

2- Giza 179.

\section{C-Weed control treatments:}

1- Saturn 50\% EC (thiobencarb) at $4.76 \mathrm{~L} \mathrm{ha}^{-1}$.

2- Ronstar 25\% EC (oxadiazon) at $1.79 \mathrm{~L} \mathrm{ha}^{-1}$.

3- Saturn $50 \%$ EC followed by $(f b)$ Granite $24 \%$ SC (penoxsulam) at $83.3 \mathrm{ml} \mathrm{ha}^{-1}$.

4- Ronstar 25\% EC fb Granite 24\% SC.

5- Hand weeding twice.

6- Unweeded (Weedy check).

Saturn 50\% EC (thiobencarb) and Ronstar 25\% EC (oxadiazon) as pre-emergence herbicides were applied mixed with sand on flooded land at 4 days after transplanting (DAT) then, kept field flooded for 4 days after herbicidal application. Granite $24 \%$ SC (penoxsulam) as post-emergence herbicide was applied at 20 DAT after Saturn and Ronstar herbicide treatment. Granite herbicide was sprayed using Gloria sprayer as 5 liters capacity with rate of water as 300 liter $\mathrm{ha}^{-1}$ on drained plots then, irrigation was introduced after 24 hours from herbicidal application. Hand weeding was done at 20 and 40 DAT.

The plots were isolated by ditches of $1.5 \mathrm{~m}$ in width to avoid any lateral movement of water. Irrigation treatments were applied after 35 days from transplanting. During irrigation time, plots were submerged to depth of $7 \mathrm{~cm}$. The applied irrigation water to each experimental plot was measured using one spile (PVC tubes) of $5 \mathrm{~cm}$ inner diameter and 80 $\mathrm{cm}$ length, which used to let water from field ditches into each plot. The effective head of water above the cross section center of irrigation spile was measured several times during irrigation and the average value was $10 \mathrm{~cm}$. The water in the canal of the field was controlled to maintain a constant head by means of fixed sliding type gates. Stage gauges were placed in each plot to measure water depth flowing through the spile. The amount of water in each application was added until it reaches the required submerged depth (7 $\mathrm{cm}$ ), and the time of the water applied was monitored using a stop watch.

The amount of water delivered through the spile tube was calculated according to Majumdar (2002) by the equation;

$$
\mathbf{q}=\mathbf{C A} \sqrt{ } \mathbf{2 g h}
$$

Where:

$\mathrm{q}=$ discharge of irrigation water $\left(\mathrm{cm}^{3} / \mathrm{s}\right)$.

$\mathrm{C}=\mathrm{a}$ discharge coefficient equal 0.62 (determined by experiment).

$\mathrm{A}=$ the inner cross section area of the irrigation spile $\left(\mathrm{cm}^{2}\right)$.

$\mathrm{g}=$ a gravity acceleration $\left(\mathrm{cm} / \mathrm{s}^{2}\right)$.

$\mathrm{h}=$ the average effective head $(\mathrm{cm})$.

The volume of water delivered for each plot ( 6 $\times 7=42 \mathrm{~m}^{2}$ ) was calculated by substituting $\mathrm{Q}$ in the following equation:

Where:

$$
\mathbf{Q}=\mathbf{q} \times \mathbf{T} \times \mathbf{n}
$$

$\mathrm{Q}=$ the volume of water $\mathrm{m}^{3} /$ plot.

$\mathrm{q}=$ the discharge $\left(\mathrm{m}^{3} / \mathrm{min}\right)$.

$\mathrm{T}=$ total irrigation time ( $\mathrm{min})$.

$\mathrm{n}=$ the number of spiles tube per each plot

\section{Sampling data recorded and calculations:}

\section{A-Weed data:}

At 50 DAT, weeds were sampled by $50 \times 50 \mathrm{~cm}$ quadrate replicated four times for each plot. Weeds were cleaned, classified into species, weed plants were obtained and weighed as fresh weight then, air dried for two days then, the air dried samples were oven dried at $70^{\circ} \mathrm{C}$ up for 48 hours to weight constant, dry weight as $\mathrm{g} \mathrm{m}^{-2}$ was determined. Weed control efficiency (WCE \%) was calculated with the following formula (Drost and Moody, 1982): 


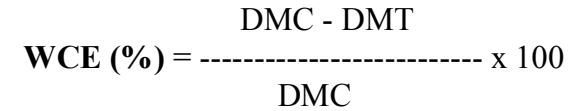

Where:

$\mathrm{DMC}=$ Weed dry matter in un-weeded treatment.

$\mathrm{DMT}=$ Weed dry matter in weed control treatment.

\section{B-Rice data:}

Rice dry weight also, was evaluated at the same time of sampling by the same method of weed dry weight. Before harvest, panicles were counted in two random quadrate of $0.50 \mathrm{~m}(50 \times 50 \mathrm{~cm})$ and number of panicles per square meter was calculated as a mean. After rice maturity, panicle weight (g) was estimated by weighing ten random panicles per plot and their average was recorded. Ten random panicles were collected from plot to estimate number of filled grain per panicle. Rice grain yield as ton $\mathrm{ha}^{-1}$ was recorded by manually harvesting of the central $5 \mathrm{~m}^{2}$ from each plot then, air dried, threshed and cleaned then adjusted at $14 \%$ moisture content.

\section{C-Productivity of irrigation water (PIW)}

The Productivity of irrigation water in $\mathrm{kg}$ grains $\mathrm{m}^{-3}$ was calculated according to (Ali et al., 2007), as follow:

$$
\text { PIW }\left(\mathbf{k g ~ m}^{-3}\right)=\frac{\text { Grain yield in } \mathrm{kg} \mathrm{ha}^{-1}}{\text { Amount of applied water in } \mathrm{m}^{3} \mathrm{ha}^{-1}}
$$

\section{D-Statistical analysis:}

Data of the experiment were subjected to proper statistical analysis of variance, according to Snedecor and Cochran (1971). Weed data were statistically analyzed by MSTATC program after transformed according to square-root transformation $(\sqrt{ }[x+0.5])$. Rice collected data were directly analyzed by MSTATC program then the means both of weeds and rice studied traits were compared by using Duncan's Multiple Range Test (Duncan, 1955).

Table (3): Some characteristics of studied herbicide, trade name, active ingredient, chemical group, mode of action,

\begin{tabular}{|c|c|c|c|}
\hline $\begin{array}{ll}\text { Herbicide } & \text { Haracter } \\
\end{array}$ & Saturn $50 \%$ EC & Ronstar $25 \%$ EC & Granite $24 \%$ SC \\
\hline Active ingredient & Thiobencarb & Oxadiazon & Penoxsulam \\
\hline Chemical group & Thiocarbamate & Oxadiazolnoe & $\begin{array}{l}\text { Sulfonamide or } \\
\text { Triazolopyrimidine }\end{array}$ \\
\hline Mode of action & $\begin{array}{l}\text { Systemic-photosynthesis } \\
\text { inhibitors }\end{array}$ & $\begin{array}{l}\text { Systemic-photosynthesis } \\
\text { inhibitors }\end{array}$ & Systemic-ALS inhibitors \\
\hline Rate $\left(\mathrm{ha}^{-1}\right)$ & $4.76 \mathrm{~L}$ & $1.79 \mathrm{~L}$ & $83.3 \mathrm{ml}$ \\
\hline Time of application (DAT) & 4 & 4 & 20 \\
\hline Target weeds & Grasses + sedges & Grasses + sedges & $\begin{array}{c}\text { Grasses }+ \text { broadleaves }+ \\
\text { sedges }\end{array}$ \\
\hline
\end{tabular}
rate per hectare, time of application and target weeds

ALS $=$ acetolactate synthase $\quad L=$ Liters

\section{RESULTS AND DISCUSSION}

The major weed species associated in this study during the two growing seasons were: a- Broadleaves including; Ammannia baccifera (Red stem), b- Sedges including; Cyperus difformis (small flower) and cGrassy weeds including; Echinochloa crus-galli (barnyardgrass).

\section{Effect of irrigation intervals (days) on:}

\subsection{Weeds:}

Dry weights of $A$. baccifera, $C$. difformis, $E$. crus-galli and their total weeds were significantly affected by irrigation intervals during two seasons (Table 4). The plots which irrigated every 9-days recorded the lowest dry matter of $A$. baccifera and $C$. difformis compared to irrigated every 3-days which gave the highest values of abovementioned weeds species in 2018 and 2019 seasons. These results are agreeing with those obtained by Bajavathinnan et al. (2011) they found that continuous high moisture content of soil allow increased germination of broadleaves seeds and sedges compared to wide irrigation interval. For E. crus-galli and total weeds, the lowest dry matter were observed under irrigation every 3-days, while the highest dry weights of both weeds were obtained by irrigation every 9-days in both seasons. It might be due to lack of oxygen under unaerobic condition, whereas grassy weeds good growth under aerobic conditions. These results are confirmed with those cited by Abou El-Darag et al. (2017).

\subsection{Rice:}

Rice dry weight at 50 DAT, number of panicles $\mathrm{m}^{-2}$, panicle weight, number of filled grains panicle ${ }^{-1}$ and grain yield were significantly affected by irrigation intervals during the two seasons (Table 5). The highest values of abovementioned traits were obtained by irrigation every 3-days compared to 9-days which achieved the lowest values of all rice studied characters in 2018 and 2019 seasons. That might be due to plants exposure to water stress during its growth and development processes in early growth stages, which cause imbalance of the vital processes inside the plant, water shortage zone, a reduction of nutrients uptake from soil and decreased plant growth, consequently a decrease in photosynthesis products, resulted that cause a decrease in grain yield and most of its components. Similar results were reported by Bozorgi et al. (2011). 
Table (4): Dry weights $\left(\mathrm{g} \mathrm{m}^{-2}\right)$ of weed species and their total weeds as influenced by irrigation intervals in 2018 and 2019 seasons

\begin{tabular}{|c|c|c|c|c|}
\hline \multirow{2}{*}{$\begin{array}{l}\text { Irrigation } \\
\text { intervals (days) }\end{array}$} & A. baccifera & C. difformis & E. crus-galli & Total weeds \\
\hline & \multicolumn{4}{|c|}{2018 season } \\
\hline 3 & $16.3(3.5 \mathrm{a})$ & $30.0(4.7 \mathrm{a})$ & $80.1(7.7 \mathrm{c})$ & $120.7(9.5 \mathrm{c})$ \\
\hline 6 & $11.1(3.1 \mathrm{~b})$ & $20.6(3.9 \mathrm{~b})$ & $117.1(9.5 \mathrm{~b})$ & $148.8(10.7 \mathrm{~b})$ \\
\hline 9 & $8.2(2.8 \mathrm{c})$ & $14.5(3.5 \mathrm{c})$ & $221.8(14.6 \mathrm{a})$ & $250.1(15.5 \mathrm{a})$ \\
\hline F test & $* *$ & $* *$ & $* *$ & $* *$ \\
\hline \multicolumn{5}{|c|}{2019 season } \\
\hline 3 & $9.4(2.6 a)$ & $18.0(3.6 \mathrm{a})$ & $60.6(6.5 c)$ & $88.1(7.7 \mathrm{c})$ \\
\hline 6 & $6.4(2.4 b)$ & $13.8(3.3 b)$ & $85.1(8.1 \mathrm{~b})$ & $105.4(9.0 \mathrm{~b})$ \\
\hline 9 & $4.5(2.1 \mathrm{c})$ & $9.4(2.9 \mathrm{c})$ & $160.4(12.2 \mathrm{a})$ & $174.3(12.7 \mathrm{a})$ \\
\hline F test & $* *$ & $* *$ & $* *$ & $* *$ \\
\hline
\end{tabular}

Table (5): Rice dry weight $\left(\mathrm{g} \mathrm{m}^{-2}\right)$, number of panicles $\mathrm{m}^{-2}$, panicle weight $(\mathrm{g})$, number of filled grains panicle ${ }^{-1}$ and grain yield $\left(\mathrm{t} \mathrm{ha}^{-1}\right)$ as influenced by irrigation intervals in 2018 and 2019 seasons

\begin{tabular}{|c|c|c|c|c|c|}
\hline $\begin{array}{l}\text { Irrigation } \\
\text { intervals (days) }\end{array}$ & $\begin{array}{l}\text { Rice dry weight } \\
\qquad\left(\mathrm{g} \mathrm{m}^{-2}\right)\end{array}$ & $\begin{array}{l}\text { Number of } \\
\text { panicles } \mathbf{m}^{-2}\end{array}$ & $\begin{array}{c}\text { Panicle } \\
\text { weight (g) }\end{array}$ & $\begin{array}{c}\text { Number of } \\
\text { filled grains } \\
\text { panicle }^{-1}\end{array}$ & $\begin{array}{l}\text { Grain yield } \\
\qquad\left(\mathrm{t} \mathrm{ha}^{-1}\right)\end{array}$ \\
\hline \multicolumn{6}{|c|}{2018 season } \\
\hline 3 & 940.9 a & 456.9 a & $2.3 \mathrm{a}$ & $99.1 \mathrm{a}$ & $8.61 \mathrm{a}$ \\
\hline 6 & $834.3 \mathrm{~b}$ & $428.5 \mathrm{~b}$ & $2.1 \mathrm{~b}$ & $95.4 \mathrm{~b}$ & $8.17 \mathrm{~b}$ \\
\hline 9 & $504.7 \mathrm{c}$ & $344.4 \mathrm{c}$ & $1.8 \mathrm{c}$ & $78.7 \mathrm{c}$ & $5.34 \mathrm{c}$ \\
\hline F test & $* *$ & $* *$ & $* *$ & $* *$ & $* *$ \\
\hline \multicolumn{6}{|c|}{2019 season } \\
\hline 3 & $1014.1 \mathrm{a}$ & $483.3 \mathrm{a}$ & $2.4 \mathrm{a}$ & 102.9 a & $8.94 \mathrm{a}$ \\
\hline 6 & $905.0 \mathrm{~b}$ & $456.9 \mathrm{~b}$ & $2.2 \mathrm{~b}$ & $99.1 \mathrm{~b}$ & $8.53 \mathrm{~b}$ \\
\hline 9 & $588.1 \mathrm{c}$ & $370.8 \mathrm{c}$ & $1.9 \mathrm{c}$ & $82.5 \mathrm{c}$ & $5.70 \mathrm{c}$ \\
\hline F test & $* *$ & $* *$ & $* *$ & $* *$ & $* *$ \\
\hline
\end{tabular}

** indicates $\mathrm{P}<0.01$. Means of each factor within each column, values $f b$ the same letters are not significantly different at $5 \%$ level, using DMRT.

\section{Effect of rice cultivars on:}

\subsection{Weeds:}

In 2018 and 2019 seasons, both of two rice cultivars (Sakha 107 and Giza 179) were significantly influenced on dry matter of $A$. baccifera, E. crus-galli and total weeds except for $C$. difformis (Table 6). Rice cultivar Giza 179 produced the lowest dry weights of all studied weeds compared to Sakha 107 which recorded the heaviest dry matter of $A$. baccifera, $E$. crus-galli and total weeds. The same trend was obtained in 2018 and 2019 seasons.

The reduction in dry weight of these weed species in Giza 179 plots may be due to the high tillering and competiveness ability of this cultivar against weeds. These results are confirmed with those obtained by Ghalwash et al. (2018). 
Table (6): Dry weights $\left(\mathrm{g} \mathrm{m}^{-2}\right)$ of weed species and their total weeds as influenced by rice cultivars in 2018 and 2019 seasons

\begin{tabular}{|c|c|c|c|c|}
\hline \multirow{2}{*}{ Rice cultivars } & A. baccifera & C. Difformis & E. crus-galli & Total weeds \\
\hline & \multicolumn{4}{|c|}{2018 season } \\
\hline Sakha 107 & $13.6(3.3 \mathrm{a})$ & 23.0 (4.1 a) & $145.8(11.0 \mathrm{a})$ & $179.8(12.3 \mathrm{a})$ \\
\hline Giza 179 & $10.1(2.9 \mathrm{~b})$ & $20.4(4.0 \mathrm{a})$ & $33.5(10.2 b)$ & $166.6(11.5 b)$ \\
\hline F test & $* *$ & NS & $* *$ & $* *$ \\
\hline \multicolumn{5}{|c|}{2019 seasons } \\
\hline Sakha 107 & $8.0(2.5 \mathrm{a})$ & $14.3(3.3 \mathrm{a})$ & 105.7 (9.2 a) & $128.0(10.2 \mathrm{a})$ \\
\hline Giza 179 & $5.6(2.2 b)$ & $13.2(3.2 \mathrm{a})$ & $98.4(8.6 b)$ & $117.2(9.5 b)$ \\
\hline F test & $* *$ & NS & $* *$ & $* *$ \\
\hline
\end{tabular}

\subsection{Rice:}

Generally, all studied characteristics of rice were significantly affected by the two rice cultivars (Sakha 107 and Giza 179) during both seasons except for rice dry weight in 2018 and 2019 seasons as well as number of filled grains panicle ${ }^{-1}$ in 2019 season (Table 7). Rice cultivar Giza 179 produced the highest number of panicles $\mathrm{m}^{-2}$ and rice grain yield in the first and second seasons as well as number of filled grains panicle ${ }^{-1}$ in the first season compared to Sakha 107. The superiority of Giza $179 \mathrm{cv}$ in these parameters might be due to characteristics of different genotypes. These finding are confirmed by El-Namaky (2007). On the other hand, rice cultivar Sakha 107 significantly exceeded Giza 179 in panicle weight during two seasons of study.

Table (7): Rice dry weight $\left(\mathrm{g} \mathrm{m}^{-2}\right)$, number of panicles $\mathrm{m}^{-2}$, panicle weight $(\mathrm{g})$, number of filled grains panicle $\mathrm{e}^{-1}$ and grain yield $\left(\mathrm{t} \mathrm{ha}^{-1}\right)$ as influenced by irrigation intervals in 2018 and 2019 seasons

\begin{tabular}{|c|c|c|c|c|c|}
\hline $\begin{array}{c}\text { Rice } \\
\text { cultivars }\end{array}$ & $\begin{array}{l}\text { Rice dry weight } \\
\left(\mathrm{g} \mathrm{m}^{-2}\right)\end{array}$ & $\begin{array}{l}\text { Number of } \\
\text { panicles } \mathbf{m}^{-2}\end{array}$ & $\begin{array}{c}\text { Panicle } \\
\text { weight }(g)\end{array}$ & $\begin{array}{l}\text { Number of filled } \\
\text { grains panicle }^{-1}\end{array}$ & $\begin{array}{c}\text { Grain yield } \\
\left(\mathbf{t ~ h a}^{-1}\right)\end{array}$ \\
\hline \multicolumn{6}{|c|}{2018 season } \\
\hline Sakha 107 & $754.7 \mathrm{a}$ & $406.1 \mathrm{~b}$ & $2.2 \mathrm{a}$ & $90.5 \mathrm{~b}$ & $7.15 \mathrm{~b}$ \\
\hline Giza 179 & $765.2 \mathrm{a}$ & $413.9 \mathrm{a}$ & $2.0 \mathrm{~b}$ & $91.7 \mathrm{a}$ & $7.60 \mathrm{a}$ \\
\hline F test & NS & $*$ & $*$ & $*$ & $* *$ \\
\hline \multicolumn{6}{|c|}{2019 season } \\
\hline Sakha 107 & $826.0 \mathrm{a}$ & $429.2 \mathrm{~b}$ & $2.2 \mathrm{a}$ & $94.7 \mathrm{a}$ & $7.46 \mathrm{~b}$ \\
\hline Giza 179 & $845.5 \mathrm{a}$ & $444.9 \mathrm{a}$ & $2.1 \mathrm{~b}$ & $95.0 \mathrm{a}$ & $7.99 \mathrm{a}$ \\
\hline F test & $\mathrm{NS}$ & $* *$ & $*$ & $\mathrm{NS}$ & $* *$ \\
\hline
\end{tabular}

\section{Effect of weed control treatments on:}

\subsection{Weeds:}

Generally, all chemical weed control treatments as well as hand weeding significantly reduced dry weights of $A$. baccifera, $C$. difformis, E. crus-galli and total weeds compared to the weedy check plots in 2018 and 2019 seasons (Table 8). Better weed control was observed in plots treated by herbicide of Ronstar $25 \%$ at 4 DAT $f b$ Granite $24 \%$ at 20 DAT $(1.79 \mathrm{~L} f b 83.3 \mathrm{ml}$ $\mathrm{ha}^{-1}$ ) respectively that leads to reduced dry weight of all tested weeds compared to weedy check plots which gave the highest values of abovementioned weed species in both two seasons. These results may be due to the efficiency of herbicide which decrease weed population and its growth. These results are confirmed with those obtained by Hassan et al. (2010).

As shown in Table (8), all herbicides treatments and hand weeding were higher weed control efficiency (WCE) compared to unweeded plots in both seasons. The better WCE (\%) was observed with the application of Ronstar 25\% EC $f b$ Granite $24 \% \quad \mathrm{SC}$ at recommended doses (88 and 93\%) in the 2018 and 2019 respectively. On the other side, the lower WCE (\%) was obtained in weedy check plots during two seasons of study. It may be due to high efficiency of herbicide treatment that lead to lower weeds dry matter accumulation as compared to other herbicide. These results are confirmed with those cited by Paramita et al. (2005). 
Table (8): Dry weights $\left(\mathrm{g} \mathrm{m}^{-2}\right)$ of weed species, their total weeds and weed control efficiency (\%) as influenced by weed control treatments in 2018 and 2019 seasons

\begin{tabular}{|c|c|c|c|c|c|}
\hline $\begin{array}{l}\text { Weed control } \\
\text { treatments }\end{array}$ & $\begin{array}{c}A . \\
\text { baccifera }\end{array}$ & $\begin{array}{c}C . \\
\text { Difformis }\end{array}$ & $\begin{array}{c}E . \\
\text { crus-galli }\end{array}$ & Total weeds & $\begin{array}{c}\text { Weed control } \\
\text { efficiency } \\
(\%)\end{array}$ \\
\hline \multicolumn{6}{|c|}{2018 season } \\
\hline Saturn 50\% EC & $12.0(3.5 \mathrm{~b})$ & $21.9(4.6 \mathrm{~b})$ & $158.2(12.4 \mathrm{~b})$ & $199.9(14.0 \mathrm{~b})$ & 53 \\
\hline Ronstar $25 \%$ EC & $9.2(3.0 \mathrm{c})$ & $17.7(4.1 \mathrm{c})$ & $135.1(11.4 \mathrm{c})$ & $165.6(12.7 \mathrm{c})$ & 61 \\
\hline Saturn $f b$ Granite $24 \%$ SC & $5.0(2.3 \mathrm{e})$ & $6.4(2.6 \mathrm{e})$ & $66.6(7.3 \mathrm{e})$ & $77.9(8.2 \mathrm{e})$ & 82 \\
\hline Ronstar $f b$ Granite & $1.4(1.2 \mathrm{f})$ & $1.4(1.4 \mathrm{f})$ & $48.6(5.2 \mathrm{f})$ & $51.6(5.4 \mathrm{f})$ & 88 \\
\hline Hand weeding & $7.2(2.7 d)$ & $9.8(3.2 \mathrm{~d})$ & $98.0(9.3 \mathrm{~d})$ & $115.0(10.3 \mathrm{~d})$ & 73 \\
\hline Weedy check & $36.3(5.9 a)$ & $72.9(8.5 \mathrm{a})$ & $331.4(18.1 \mathrm{a})$ & $429.2(20.7 \mathrm{a})$ & -- \\
\hline F test & ** & $* *$ & $* *$ & $* *$ & \\
\hline \multicolumn{6}{|c|}{2019 season } \\
\hline Saturn 50\% EC & $7.6(2.8 \mathrm{~b})$ & $13.4(3.6 \mathrm{~b})$ & $121.3(10.8 \mathrm{~b})$ & $142.3(11.8 \mathrm{~b})$ & 56 \\
\hline Ronstar $25 \%$ EC & $4.7(2.2 \mathrm{c})$ & $10.6(3.3 \mathrm{c})$ & $110.2(10.3 \mathrm{c})$ & $125.4(11.0 \mathrm{c})$ & 61 \\
\hline Saturn $f b$ Granite $24 \%$ SC & $2.3(1.6 \mathrm{e})$ & $3.4(1.9 \mathrm{e})$ & $40.2(5.6 \mathrm{e})$ & $45.9(6.1 \mathrm{e})$ & 86 \\
\hline Ronstar $f b$ Granite & $0.6(1.0 \mathrm{f})$ & $1.3(1.2 \mathrm{f})$ & $22.4(3.6 \mathrm{f})$ & $24.3(3.7 \mathrm{f})$ & 93 \\
\hline Hand weeding & $3.2(1.9 \mathrm{~d})$ & $7.4(2.8 \mathrm{~d})$ & $64.7(7.5 \mathrm{~d})$ & $75.2(8.3 \mathrm{~d})$ & 77 \\
\hline Weedy check & $22.4(4.6 \mathrm{a})$ & $46.5(6.8 \mathrm{a})$ & $253.4(15.8 \mathrm{a})$ & $322.3(17.9 \mathrm{a})$ & -- \\
\hline F test & $* *$ & $* *$ & $* *$ & $* *$ & \\
\hline
\end{tabular}

\subsection{Rice:}

All chemical weed control treatments and hand weeding significantly increased rice dry weight, number of panicles $\mathrm{m}^{-2}$, panicle weight, number of filled grains panicle ${ }^{-1}$ and grain yield of compared to the untreated plots during two seasons (Table 9). Application of Ronstar at $1.79 \mathrm{~L} \mathrm{ha}^{-1} \mathrm{fb}$ Granite at 83.3 $\mathrm{ml} \mathrm{ha}{ }^{-1}$ respectively recorded the highest values of all studies rice characteristics as compared to unweeded plots in both seasons.

This increase may be due to the high efficiency of chemical control in reducing weed competiveness ability, which lead to more absorption of nutrients and water by rice plant, enhanced metabolites synthesized processes and produced more grain yield of rice as reported by Shebl et al. (2009).

Table (9): Rice dry weight $\left(\mathrm{g} \mathrm{m}^{-2}\right)$, number of panicles $\mathrm{m}^{-2}$, panicle weight $(\mathrm{g})$, number of filled grains panicle $\mathrm{e}^{-1}$ and grain yield $\left(\mathrm{t} \mathrm{ha}^{-1}\right)$ as influenced by weed control treatments in 2018 and 2019 seasons

\begin{tabular}{|c|c|c|c|c|c|}
\hline $\begin{array}{l}\text { Weed control } \\
\text { Treatments }\end{array}$ & $\begin{array}{l}\text { Rice dry weight } \\
\qquad\left(\mathrm{g} \mathrm{m}^{-2}\right)\end{array}$ & $\begin{array}{l}\text { Number of } \\
\text { panicles } \mathbf{m}^{-2}\end{array}$ & $\begin{array}{c}\text { Panicle } \\
\text { weight }(\mathrm{g})\end{array}$ & $\begin{array}{l}\text { Number of filled } \\
\text { grains panicle }^{-1}\end{array}$ & $\begin{array}{c}\text { Grain yield } \\
\left(\mathrm{t} \mathrm{ha}^{-1}\right)\end{array}$ \\
\hline \multicolumn{6}{|c|}{2018 season } \\
\hline Saturn 50\% EC & $612.3 \mathrm{e}$ & $398.6 \mathrm{e}$ & $2.0 \mathrm{~d}$ & $85.4 \mathrm{e}$ & $7.17 \mathrm{e}$ \\
\hline Ronstar $25 \%$ EC & $784.3 \mathrm{~d}$ & $406.9 \mathrm{~d}$ & $2.1 \mathrm{c}$ & $89.2 \mathrm{~d}$ & $7.47 \mathrm{~d}$ \\
\hline Saturn $f b$ Granite $24 \%$ SC & $975.4 \mathrm{~b}$ & $463.9 \mathrm{~b}$ & $2.2 \mathrm{~b}$ & $100.3 \mathrm{~b}$ & $8.81 \mathrm{~b}$ \\
\hline Ronstar $f b$ Granite & $1059.1 \mathrm{a}$ & $494.4 \mathrm{a}$ & $2.3 \mathrm{a}$ & $105.1 \mathrm{a}$ & $9.51 \mathrm{a}$ \\
\hline Hand weeding & $862.4 \mathrm{c}$ & $425.0 \mathrm{c}$ & $2.2 \mathrm{~b}$ & $95.3 \mathrm{c}$ & $8.10 \mathrm{c}$ \\
\hline Weedy check & $266.1 \mathrm{f}$ & $270.8 \mathrm{f}$ & $1.6 \mathrm{e}$ & $70.2 \mathrm{f}$ & $3.18 \mathrm{f}$ \\
\hline F test & $* *$ & $* *$ & $* *$ & $* *$ & $* *$ \\
\hline \multicolumn{6}{|c|}{2019 season } \\
\hline Saturn 50\% EC & $733.4 \mathrm{e}$ & $413.9 \mathrm{~d}$ & $2.1 \mathrm{~d}$ & $88.4 \mathrm{e}$ & $7.58 \mathrm{e}$ \\
\hline Ronstar $25 \%$ EC & $832.9 \mathrm{~d}$ & $436.1 \mathrm{c}$ & $2.2 \mathrm{c}$ & $93.6 \mathrm{~d}$ & $7.82 \mathrm{~d}$ \\
\hline Saturn $f b$ Granite $24 \%$ SC & $1038.6 \mathrm{~b}$ & $490.3 \mathrm{~b}$ & $2.3 \mathrm{~b}$ & $103.9 \mathrm{~b}$ & $9.26 \mathrm{~b}$ \\
\hline Ronstar $f b$ Granite & $1141.6 \mathrm{a}$ & $518.1 \mathrm{a}$ & $2.4 \mathrm{a}$ & $109.0 \mathrm{a}$ & $9.85 \mathrm{a}$ \\
\hline Hand weeding & $924.1 \mathrm{c}$ & $450.0 \mathrm{c}$ & $2.2 \mathrm{c}$ & $98.9 \mathrm{c}$ & $8.33 \mathrm{c}$ \\
\hline Weedy check & $343.8 \mathrm{f}$ & $313.9 \mathrm{f}$ & $1.7 \mathrm{e}$ & $75.0 \mathrm{f}$ & $3.50 \mathrm{f}$ \\
\hline F test & $* *$ & $* *$ & $* *$ & $* *$ & $* *$ \\
\hline
\end{tabular}




\section{Effect of the interactions on:}

\subsection{Weeds:}

4.1.1. Effect of the interaction between irrigation intervals and weed control treatments

Generally, all chemical and manual control caused a significant reduction in dry weights of $C$. difformis, E. crus-galli and total weeds under all irrigation intervals compared to weedy check during the two seasons of study (Table 10). Plots which were irrigated every 3-days treated by Ronstar $f b$ Granite at recommended doses achieved the best weed control and recorded the lowest dry weights of all studied weed species and total weeds as well as every 6-days under the same of herbicide treatment for $C$. difformis during both seasons. These results may be due to important role of water in raising herbicide absorption and efficiency which leads to more suppression for weed seeds germination and kill germinated weeds. These results are confirmed with those cited by Abou ELDarag et al. (2017), Abd El-Naby and Mahmoud (2018). On the other hand, the heaviest dry weight of $C$. difformis was observed at the combined effect of irrigation interval every 3 -day under weedy check plots.
While, irrigation interval every 9-days under weedy check plots recorded the highest dry weights of E. crusgalli and total weeds in 2018 and 2019 seasons.

\subsubsection{Effect of the interaction between rice cultivars and weed control treatments}

All chemical and manual weed control caused a significant reduction in dry weights of E. crus-galli and total weeds under two rice cultivars during two seasons (Table 11). Application of per-emergence herbicide (Ronstar) $f b$ post-emergence herbicide (Granite) at recommended doses with Giza $179 \mathrm{cv}$ recorded the lowest dry weights of E. crus-galli and total weeds in 2018 and 2019 seasons as well as the same treatment of herbicide in Sakha 107 plots for E. crus-galli in 2018 season. On the other hand, Sakha $107 \mathrm{cv}$ under weedy check plots recorded the highest dry weight of abovementioned traits in the first and second seasons as well as with Giza $179 \mathrm{cv}$ in unweeded plots for $E$. crus-galli in the first season. It may be due to the high efficacy of herbicide application in controlling weeds and high competitive ability for rice cultivar 179 against weeds. These results are confirmed with those cited by Shebl et al. (2009).

Table (10): Effect of the interaction between irrigation intervals and weed control treatments on dry weights $\left(\mathrm{g} \mathrm{m}^{-2}\right)$ of C. difformis, E. crus-galli and total weeds in 2018 and 2019 seasons

\begin{tabular}{|c|c|c|c|c|c|c|}
\hline \multirow{2}{*}{$\begin{array}{c}\text { Irrigation } \\
\text { intervals } \\
\text { (days) }\end{array}$} & \multicolumn{6}{|c|}{ Weed control treatments } \\
\hline & Saturn & Ronstar & $\begin{array}{c}\text { Saturn } f b \\
\text { Granite }\end{array}$ & $\begin{array}{c}\text { Ronstar } f b \\
\text { Granite }\end{array}$ & $\begin{array}{c}\text { Hand } \\
\text { weeding }\end{array}$ & Weedy check \\
\hline \multicolumn{7}{|c|}{$\begin{array}{l}\text { C. difformis } \\
2018 \text { season }\end{array}$} \\
\hline 3 & $34.8(5.9 \mathrm{~d})$ & $30.4(5.5 \mathrm{~d})$ & $7.5(2.8 \mathrm{~h})$ & $0.5(0.9 \mathrm{k})$ & $11.4(3.4 \mathrm{fg})$ & $95.6(9.8 \mathrm{a})$ \\
\hline 6 & $19.6(4.5 \mathrm{e})$ & $13.8(3.8 \mathrm{f})$ & $4.7(2.3 \mathrm{ij})$ & $0.9(1.2 \mathrm{k})$ & 9.9 (3.2 gh) & $75.0(8.7 \mathrm{~b})$ \\
\hline 9 & $11.5(3.4 \mathrm{fg})$ & $9.0(3.0 \mathrm{gh})$ & 7.0 (2.7 hi) & $3.5(2.0 \mathrm{j})$ & $8.1(2.9 \mathrm{gh})$ & $48.0(7.0 \mathrm{c})$ \\
\hline \multicolumn{7}{|c|}{2019 season } \\
\hline 3 & $18.0(4.3 \mathrm{~d})$ & $13.9(3.8 \mathrm{ef})$ & $1.1(1.2 \mathrm{j})$ & $0.1(0.8 \mathrm{k})$ & $9.7(3.2 \mathrm{~g})$ & $65.3(8.1 \mathrm{a})$ \\
\hline 6 & $15.8(4.0 \mathrm{de})$ & $12.6(3.6 \mathrm{f})$ & $3.5(2.0 \mathrm{i})$ & $0.1(0.8 \mathrm{k})$ & $6.7(2.7 \mathrm{~h})$ & $44.3(6.7 b)$ \\
\hline 9 & $6.4(2.6 \mathrm{~h})$ & $5.3(2.4 \mathrm{~h})$ & $5.5(2.4 \mathrm{~h})$ & $3.6(2.0 \mathrm{i})$ & $5.6(2.4 \mathrm{~h})$ & $29.9(5.5 \mathrm{c})$ \\
\hline \multicolumn{7}{|c|}{$\begin{array}{l}\text { E. crus-galli } \\
2018 \text { season }\end{array}$} \\
\hline 3 & 95.8 (9.8 i) & $74.8(8.6 \mathrm{j})$ & $16.2(4.0 \mathrm{~m})$ & $1.7(1.5 \mathrm{o})$ & $43.4(6.6 \mathrm{k})$ & $248.5(15.8 \mathrm{c})$ \\
\hline 6 & $162.9(12.7 \mathrm{f})$ & $131.3(11.4 \mathrm{~h})$ & $31.6(5.5 \mathrm{c})$ & $5.0(2.3 \mathrm{n})$ & $51.2(7.1 \mathrm{k})$ & $320.5(17.9 \mathrm{~b})$ \\
\hline 9 & $216.0(14.7 \mathrm{~d})$ & $199.1(14.1 \mathrm{e})$ & $151.9(12.3 \mathrm{fg})$ & $139.0(11.8 \mathrm{gh})$ & $199.3(14.1 \mathrm{e})$ & $425.3(20.6 a)$ \\
\hline \multicolumn{7}{|c|}{2019 season } \\
\hline 3 & $69.5(8.2 \mathrm{i})$ & $62.6(7.8 \mathrm{i})$ & $8.7(3.0 \mathrm{~m})$ & $0.2(0.8 \mathrm{o})$ & $23.2(4.9 \mathrm{k})$ & $199.4(14.1 \mathrm{c})$ \\
\hline 6 & $113.4(10.6 \mathrm{~g})$ & $103.4(10.1 \mathrm{~h})$ & $17.9(4.21)$ & $4.0(1.9 \mathrm{n})$ & $39.1(6.3 \mathrm{j})$ & $233.2(15.2 \mathrm{~d})$ \\
\hline 9 & $181.1(13.5 \mathrm{~b})$ & $164.4(12.8 \mathrm{e})$ & $94.2(9.7 \mathrm{~h})$ & $63.1(7.9 \mathrm{i})$ & $131.8(11.4 \mathrm{f})$ & $327.8(18.1 \mathrm{a}$ \\
\hline \multicolumn{7}{|c|}{ Total weeds } \\
\hline \multicolumn{7}{|c|}{2018 season } \\
\hline 3 & $147.9(12.1 \mathrm{~h})$ & $119.0(10.9 \mathrm{i})$ & $27.5(5.21)$ & $2.3(1.6 \mathrm{n})$ & $63.5(8.0 \mathrm{j})$ & $364.0(19.1 \mathrm{c})$ \\
\hline 6 & 194.5 (13.9 f) & $153.4(12.3 \mathrm{gh})$ & $42.4(6.5 \mathrm{k})$ & $6.4(2.5 \mathrm{~m})$ & $68.7(8.3 \mathrm{j})$ & $427.6(20.7 \mathrm{~b})$ \\
\hline 9 & $257.4(16.0 \mathrm{~d})$ & $224.3(15.0 \mathrm{e})$ & $163.8(12.8 \mathrm{~g})$ & $146.3(12.1 \mathrm{~h})$ & $212.7(14.6 \mathrm{e})$ & $496.0(22.3 \mathrm{a})$ \\
\hline \multicolumn{7}{|c|}{2019 season } \\
\hline 3 & $96.0(7.9 \mathrm{~g})$ & $81.6(8.9 \mathrm{~h})$ & $11.4(3.4 \mathrm{~m})$ & $0.3(0.9$ o) & $36.2(6.0 \mathrm{k})$ & $302.8(17.4 \mathrm{~b})$ \\
\hline 6 & $139.0(11.8 \mathrm{e})$ & $122.0(11.0 \mathrm{f})$ & $24.1(4.91)$ & $4.1(2.0 \mathrm{n})$ & $48.8(48.8 \mathrm{j})$ & $294.0(17.1 \mathrm{~b})$ \\
\hline 9 & $192.0(13.9 \mathrm{c})$ & $172.6(13.1 \mathrm{~d})$ & $102.1(10.1 \mathrm{~g})$ & $68.4(8.3) \mathrm{i}$ & $140.6(11.8 \mathrm{e})$ & $370.1(19.2 \mathrm{a})$ \\
\hline
\end{tabular}

Means $f b$ a common letter within a season are not significantly differed at 5\% level, using DMRT. Values within parentheses are transformed 
Table (11): Effect of the interaction between rice cultivars and weed control treatments on dry weights $\left(\mathrm{g} \mathrm{m}^{-2}\right)$ of $E$. crus-galli and total weeds $\mathrm{m}^{-2}$ in 2018 and 2019 seasons

\begin{tabular}{|c|c|c|c|c|}
\hline \multirow{3}{*}{$\begin{array}{l}\text { Weed control } \\
\text { treatments }\end{array}$} & \multicolumn{2}{|c|}{ E. crus-galli } & \multicolumn{2}{|c|}{ Total weeds } \\
\hline & \multicolumn{4}{|c|}{ Rice cultivars } \\
\hline & Sakha 107 & Giza 179 & Sakha 107 & Giza 179 \\
\hline \multicolumn{5}{|c|}{2018 season } \\
\hline Saturn 50\% EC & $170.7(13.0 \mathrm{~b})$ & $145.7(11.8 \mathrm{c})$ & $206.9(14.4 \mathrm{c})$ & $193.0(13.7 \mathrm{~d})$ \\
\hline Ronstar $25 \%$ EC & $148.8(12.1 \mathrm{c})$ & $121.4(10.7 d)$ & $178.9(13.4 \mathrm{~d})$ & $152.2(12.1 \mathrm{e})$ \\
\hline Saturn $f b$ Granite $24 \%$ SC & $68.1(7.7 \mathrm{~g})$ & $65.0(6.9 \mathrm{~h})$ & $80.2(8.5 \mathrm{~h})$ & $75.6(7.8 \mathrm{i})$ \\
\hline Ronstar $f b$ Granite & $48.3(5.4 \mathrm{i})$ & $48.9(5.0 \mathrm{i})$ & $51.6(5.7 \mathrm{j})$ & $51.7(5.2 \mathrm{k})$ \\
\hline Hand weeding & $103.0(9.7 \mathrm{e})$ & $92.9(8.8 \mathrm{f})$ & $121.7(10.8 \mathrm{f})$ & $108.2(9.8 \mathrm{~g})$ \\
\hline Weedy check & $335.9(18.3 \mathrm{a}$ & $326.9(17.9 \mathrm{a})$ & $439.7(21.0 \mathrm{a})$ & $418.7(20.4 \mathrm{~b})$ \\
\hline \multicolumn{5}{|c|}{2019 season } \\
\hline Saturn 50\% EC & $132.1(11.4 \mathrm{c})$ & $110.6(10.1 \mathrm{e})$ & $155.1(12.4 \mathrm{c})$ & $129.6(11.1 \mathrm{e})$ \\
\hline Ronstar $25 \%$ EC & $118.2(10.8 \mathrm{~d})$ & $102.3(9.7 \mathrm{f})$ & $135.3(11.6 \mathrm{~d})$ & $115.5(10.4 \mathrm{f})$ \\
\hline Saturn $f b$ Granite $24 \%$ SC & $36.5(5.7 \mathrm{~h})$ & $44.0(5.5 \mathrm{~h})$ & $42.6(6.2 \mathrm{~h})$ & $49.1(6.0 \mathrm{~h})$ \\
\hline Ronstar $f b$ Granite & $23.2(3.8 \mathrm{i})$ & $21.6(3.3 \mathrm{j})$ & $25.1(4.0 \mathrm{i})$ & $23.5(3.4 \mathrm{j})$ \\
\hline Hand weeding & $58.9(7.4 \mathrm{~g})$ & $70.4(7.6 \mathrm{~g})$ & $70.1(8.2 \mathrm{~g})$ & $80.3(8.4 \mathrm{c})$ \\
\hline Weedy check & $265.3(16.3 \mathrm{a})$ & $241.6(15.4 \mathrm{~b})$ & $339.5(18.4 \mathrm{a})$ & $305.1(17.4)$ \\
\hline
\end{tabular}

Means $f b$ a common letter within a season are not significantly differed at $5 \%$ level, using DMRT. Values within parentheses are transformed

\subsubsection{Effect of the interaction among irrigation intervals, rice cultivars and weed control treatments}

Total weeds dry weight was greatly influenced by the interaction among irrigation intervals, rice cultivars and weed control treatments during the two seasons (Table 12). Irrigation interval every 3-days with two rice cultivars treated by Ronstar $f b$ Granite at recommended doses as well as irrigation every 6-days with Giza 179 under the same herbicide treatment achieved the best weed control and recorded the lowest total weeds dry weight. While, the highest dry weight of total weeds was observed in plots which irrigated every 9-days with Giza $179 \mathrm{cv}$ under weedy check plots in 2018 and 2019 seasons. This may be due to the important role of water in increasing herbicide efficiency as well as inhibition and kill weeds and highly ability competitiveness for Giza $179 \mathrm{cv}$ against weeds, lead to good growth for rice plants. These results are confirmed with those cited by Abd El- Naby and Mahmoud (2018).

Table (12): Effect of the interaction among irrigation intervals (days), rice cultivars and weed control treatments on total weeds dry weight $\left(\mathrm{g} \mathrm{m}^{-2}\right)$ in 2018 and 2019 seasons

\begin{tabular}{|c|c|c|c|c|c|c|c|}
\hline \multirow{2}{*}{$\begin{array}{c}\text { Irrigation } \\
\text { intervals } \\
\text { (days) }\end{array}$} & \multirow{2}{*}{$\begin{array}{c}\text { Rice } \\
\text { cultivars }\end{array}$} & \multicolumn{6}{|c|}{ Weed control treatments } \\
\hline & & Saturn & Ronstar & $\begin{array}{c}\text { Saturn } f b \\
\text { Granite }\end{array}$ & $\begin{array}{c}\text { Ronstar } f b \\
\text { Granite }\end{array}$ & $\begin{array}{c}\text { Hand } \\
\text { weeding }\end{array}$ & $\begin{array}{l}\text { Weedy } \\
\text { check }\end{array}$ \\
\hline \multicolumn{8}{|c|}{2018 seasons } \\
\hline \multirow{2}{*}{3} & Sakha 107 & $173.6(13.2 \mathrm{ij})$ & $142.2(11.91)$ & $33.3(5.7 q)$ & $3.0(1.9 \mathrm{t})$ & $76.8(8.8 \mathrm{o})$ & $402.5(20.1 \mathrm{c})$ \\
\hline & Giza 179 & $122.3(11.1 \mathrm{~m})$ & $95.79 .8 \mathrm{n})$ & $21.7(4.7 \mathrm{r})$ & $1.5(1.4 \mathrm{t})$ & $50.3(7.1 \mathrm{p})$ & $325.5(18.1 \mathrm{~d})$ \\
\hline \multirow{2}{*}{6} & Sakha 107 & $225.9(15.1 \mathrm{fg})$ & 188.3 (13.7 hi) & $56.9(7.6 \mathrm{p})$ & $9.6(3.2 \mathrm{~s})$ & $84.0(9.2 \mathrm{no})$ & $455.6(21.4 b)$ \\
\hline & Giza 179 & $163.1(12.8 \mathrm{jk})$ & $118.6(10.9 \mathrm{~m})$ & $27.9(5.3 \mathrm{qr})$ & $3.1(1.9 \mathrm{t})$ & $53.3(7.3 \mathrm{p})$ & $399.5(20.0 \mathrm{c})$ \\
\hline \multirow{2}{*}{9} & Sakha 107 & $221.1(14.9 \mathrm{fg})$ & $206.3(14.4 \mathrm{gh})$ & $150.5(12.3 \mathrm{kl})$ & $142.1(11.91)$ & $204.4(14.3 \mathrm{gh})$ & $461.1(21.5 b)$ \\
\hline & Giza 179 & $293.7(17.2 \mathrm{e})$ & $242.2(15.6 \mathrm{f})$ & $177.1(13.3 \mathrm{ij})$ & $150.1(12.3 \mathrm{kl})$ & $220.9(14.9 \mathrm{fg})$ & $530.9(23.1 \mathrm{a})$ \\
\hline \multicolumn{8}{|c|}{2019 seasons } \\
\hline \multirow{2}{*}{3} & Sakha 107 & $124.6(11.2 \mathrm{i})$ & $106.8(10.4 \mathrm{jk})$ & $15.8(4.0 \mathrm{q})$ & $0.4(0.9 \mathrm{~s})$ & 40.7 (6.4 no) & $328.4(18.3 \mathrm{~b})$ \\
\hline & Giza 179 & $67.4(8.21)$ & $56.4(7.5 \mathrm{~m})$ & $7.0(2.7 \mathrm{r})$ & $0.2(0.9 \mathrm{~s})$ & $31.7(5.7 \mathrm{p})$ & $277.1(16.7 \mathrm{c})$ \\
\hline \multirow{2}{*}{6} & Sakha 107 & $162.2(12.8 \mathrm{gh})$ & $148.6(12.2 \mathrm{~h})$ & $33.0(5.8$ op $)$ & $7.5(2.8 \mathrm{r})$ & $55.0(7.4 \mathrm{~m})$ & $341.5(18.5 b)$ \\
\hline & Giza 179 & $115.9(10.8 \mathrm{ij})$ & $95.4(9.8 \mathrm{k})$ & $15.1(3.91)$ & $0.8(1.1 \mathrm{~s})$ & $42.6(6.5 n)$ & $246.6(15.7 \mathrm{~d})$ \\
\hline \multirow{2}{*}{9} & Sakha 107 & $178.5(13.4 \mathrm{fg})$ & $150.5(12.3 \mathrm{~h})$ & $79.0(8.91)$ & $67.4(8.21)$ & 114.7 (10.7 ij) & $348.7(18.7 \mathrm{~b})$ \\
\hline & Giza 179 & $205.8(14.4 \mathrm{e})$ & 194.8 (14.0 ef) & $125.2(11.2 \mathrm{i})$ & $69.4(8.31)$ & $166.4(12.9 \mathrm{gh})$ & $391.4(19.8 \mathrm{a})$ \\
\hline
\end{tabular}

Means $f b$ a common letter within a season are not significantly differed at $5 \%$ level, using DMRT. Values within parentheses are transformed. 
4.2. Rice:

4.2.1. Effect of the interaction between irrigation intervals and rice cultivars

Rice dry weight, number of panicles $\mathrm{m}^{-2}$, panicle weight, number of filled grains panicle ${ }^{-1}$ and grain yield were significantly affected by the interaction between irrigation intervals and rice cultivars during two seasons (Table 13). Irrigation interval every 3-days with Giza $179 \mathrm{cv}$ recorded the highest rice dry weight, number of panicles $\mathrm{m}^{-2}$, number of filled grains panicle ${ }^{-1}$ and grain yield while, the highest panicle weight was detected from the combined effect of the same irrigation interval with Sakha $107 \mathrm{cv}$ in 2018 and 2019 season. On the other hand, weedy check plots cultivated with Giza 179 and irrigated every 9-days gave the lowest values of all rice studied traits in the two growing seasons as mentioned by Abou El-Hassan et al. (2006).

Table (13): Effect of the interaction between irrigation intervals and rice cultivars on rice dry weight $\left(\mathrm{g} \mathrm{m}^{-2}\right)$, number of panicles $\mathrm{m}^{-2}$, panicle weight $(\mathrm{g})$, number of filled grains panicle $\mathrm{e}^{-1}$ and grain yield $\left(\mathrm{t} \mathrm{ha} \mathrm{h}^{-1}\right)$ in 2018 and 2019 seasons

\begin{tabular}{|c|c|c|c|c|c|c|c|c|c|c|}
\hline \multirow[t]{3}{*}{$\begin{array}{c}\text { Irrigation } \\
\text { intervals } \\
\text { (days) }\end{array}$} & \multicolumn{2}{|c|}{$\begin{array}{l}\text { Rice dry weight } \\
\qquad\left(\mathrm{g} \mathrm{m}^{-2}\right)\end{array}$} & \multicolumn{2}{|c|}{$\begin{array}{l}\text { Number of } \\
\text { panicles } \mathbf{~ m}^{-2}\end{array}$} & \multicolumn{2}{|c|}{$\begin{array}{c}\text { Panicle } \\
\text { weight (g) }\end{array}$} & \multicolumn{2}{|c|}{$\begin{array}{l}\text { Number of filled } \\
\text { grains panicle }^{-1}\end{array}$} & \multicolumn{2}{|c|}{$\begin{array}{l}\text { Grain yield } \\
\quad\left(\mathrm{t} \mathrm{ha}^{-1}\right)\end{array}$} \\
\hline & \multicolumn{8}{|c|}{ Rice cultivars } & \multirow[b]{2}{*}{$\begin{array}{c}\text { Sakha } \\
107\end{array}$} & \multirow[b]{2}{*}{$\begin{array}{r}\text { Giza } \\
179\end{array}$} \\
\hline & $\begin{array}{c}\text { Sakha } \\
107\end{array}$ & $\begin{array}{c}\text { Giza } \\
179\end{array}$ & $\begin{array}{c}\text { Sakha } \\
107\end{array}$ & $\begin{array}{c}\text { Giza } \\
179\end{array}$ & $\begin{array}{c}\text { Sakha } \\
107\end{array}$ & $\begin{array}{c}\text { Giza } \\
179\end{array}$ & $\begin{array}{c}\text { Sakha } \\
107\end{array}$ & $\begin{array}{c}\text { Giza } \\
179\end{array}$ & & \\
\hline \multicolumn{11}{|c|}{2018 season } \\
\hline 3 & $890.0 \mathrm{~b}$ & $991.8 \mathrm{a}$ & $437.5 \mathrm{c}$ & $476.4 \mathrm{a}$ & $2.4 \mathrm{a}$ & $2.2 \mathrm{~b}$ & $95.5 \mathrm{c}$ & $102.8 \mathrm{a}$ & $7.96 \mathrm{c}$ & $9.27 \mathrm{a}$ \\
\hline 6 & $780.4 \mathrm{c}$ & $888.2 \mathrm{~b}$ & $408.3 \mathrm{~d}$ & $448.6 \mathrm{~b}$ & $2.1 \mathrm{c}$ & $2.0 \mathrm{~d}$ & $93.3 \mathrm{~d}$ & $97.6 \mathrm{~b}$ & $7.59 \mathrm{~d}$ & $8.75 b$ \\
\hline 9 & $593.8 \mathrm{~d}$ & $415.5 \mathrm{e}$ & $372.2 \mathrm{e}$ & $316.7 \mathrm{f}$ & $1.9 \mathrm{e}$ & $1.8 \mathrm{f}$ & $82.7 \mathrm{e}$ & $74.8 \mathrm{f}$ & $5.90 \mathrm{e}$ & $4.78 \mathrm{f}$ \\
\hline \multicolumn{11}{|c|}{2019 season } \\
\hline 3 & $953.9 \mathrm{~b}$ & $1074.3 \mathrm{a}$ & $459.7 \mathrm{c}$ & 506.9 a & $2.5 \mathrm{a}$ & $2.3 \mathrm{~b}$ & $100.0 \mathrm{~b}$ & $105.7 \mathrm{a}$ & $8.28 \mathrm{c}$ & $9.61 \mathrm{a}$ \\
\hline 6 & $834.7 \mathrm{c}$ & $975.3 \mathrm{~b}$ & $430.6 \mathrm{~d}$ & $483.3 \mathrm{~b}$ & $2.2 \mathrm{~b}$ & $2.1 \mathrm{c}$ & $97.9 \mathrm{c}$ & $100.3 \mathrm{~b}$ & $7.95 \mathrm{~d}$ & $9.11 \mathrm{~b}$ \\
\hline 9 & $689.4 \mathrm{~d}$ & $486.8 \mathrm{e}$ & $397.2 \mathrm{e}$ & $344.4 \mathrm{f}$ & $2.0 \mathrm{~d}$ & $1.8 \mathrm{e}$ & $86.1 \mathrm{~d}$ & $78.9 \mathrm{e}$ & $6.16 \mathrm{e}$ & $5.24 \mathrm{f}$ \\
\hline
\end{tabular}

Means $f b$ a common letter within a season are not significantly differed at $5 \%$ level, using DMRT

\subsubsection{Effect of the interaction between irrigation} intervals and weed control treatments

Rice number of panicles $\mathrm{m}^{-2}$ and grain yield were significantly influenced by the interaction between irrigation intervals and weed control treatments during two seasons (Table 14). The highest number of panicles $\mathrm{m}^{-2}$ and grain yield of rice were obtained when weeds were controlled by herbicide of Ronstar $f b$ Granite at $\left(\begin{array}{lllll}1.79 & \mathrm{~L} f b & 83.3 & \mathrm{ml} \mathrm{ha} & \end{array}\right)$ respectively with irrigation interval every 3 -days in the first and second seasons as well as rice grain yield under irrigation interval every 6-days at the same herbicide treatment in the first season only. While, the lowest values of these traits were observed in weedy check plots under irrigation every 9-days during two growing seasons. This may be due to the high efficiency of herbicide application under irrigation every 3 and 6 days to reduced weed competition, weakness its growth consequently allowed to good growth for rice plants that lead to increasing yield and its attributes. Similar results were reported by Sarkar et al. (2017).

\subsubsection{Effect of the interaction among irrigation} intervals, rice cultivars and weed control treatments

Rice number of panicles $\mathrm{m}^{-2}$ and grain yield were significantly affected by the interaction among irrigation intervals, rice cultivars and weed control treatment during two seasons (Table 15). The high number of panicle $\mathrm{m}^{-2}$ and rice grain yield achieved by irrigation every 3- days with Giza $179 \mathrm{cv}$ treated by Ronstar 25\% EC at $1.79 \mathrm{~L} \mathrm{ha}^{-1} \mathrm{fb}$ Granite $24 \% \mathrm{SC}$ at $83.3 \mathrm{ml} \mathrm{ha}{ }^{-1}$ without significant differences with irrigation every 6-days for Giza $179 \mathrm{cv}$ under the same herbicide treatment in 2018 and 2019 seasons. The superiority Giza $179 \mathrm{cv}$ in this characteristics under two irrigation intervals ( 3 and 6-days) when treated by herbicide may be due to the high efficiency of herbicide in controlling of dominant weeds that lead to reduced weeds competition, give a good chance for rice growth, increasing yield and its components. These results are in agreement by Abd El-Naby and Mahmoud (2018). On the other hand, the lowest number of panicles $\mathrm{m}^{-2}$ and rice grain yield were found at irrigation every 9- days with Giza $179 \mathrm{cv}$ under weedy check plots during two growing seasons. It might be due to higher weed-crop competition with limited resources under these conditions as reported by Abou El-Darag et al. (2017). In case of water shortage (irrigation every 9-days), the highest number of panicle $\mathrm{m}^{-2}$ and rice grain yield were recorded by Sakha 107 treated with Ronstar $f b$ Granite at recommended doses in 2018 and 2019 seasons. 
Table (14): Effect of the interaction between irrigation intervals and weed control treatments on rice number of panicles $\mathrm{m}^{-2}$ and grain yield $\left(\mathrm{t} \mathrm{ha}^{-1}\right)$ in 2018 and 2019 seasons

\begin{tabular}{|c|c|c|c|c|c|c|}
\hline \multirow{3}{*}{ Weed control treatments } & \multicolumn{3}{|c|}{ Number of panicles $\mathrm{m}^{-2}$} & \multicolumn{3}{|c|}{ Grain yield $\left(\mathrm{t} \mathrm{ha}^{-1}\right)$} \\
\hline & \multicolumn{6}{|c|}{ Irrigation intervals (days) } \\
\hline & 3 & 6 & 9 & 3 & 6 & 9 \\
\hline & \multicolumn{6}{|c|}{2018 season } \\
\hline Saturn 50\% EC & $437.4 \mathrm{e}$ & $416.7 \mathrm{f}$ & $341.7 \mathrm{i}$ & $8.41 \mathrm{~g}$ & $7.93 \mathrm{~h}$ & 5.171 \\
\hline Ronstar $25 \%$ EC & $437.5 \mathrm{e}$ & $433.3 \mathrm{e}$ & $350.0 \mathrm{hi}$ & $8.66 \mathrm{f}$ & $8.38 \mathrm{~g}$ & 5.371 \\
\hline Saturn $f b$ Granite $24 \%$ SC & $512.5 \mathrm{~b}$ & $487.5 \mathrm{c}$ & $391.7 \mathrm{~g}$ & $10.14 \mathrm{~b}$ & $9.87 \mathrm{c}$ & $6.43 \mathrm{j}$ \\
\hline Ronstar $f b$ Granite & $545.8 \mathrm{a}$ & $520.8 \mathrm{~b}$ & $416.7 \mathrm{f}$ & $10.65 \mathrm{a}$ & $10.45 \mathrm{a}$ & $7.42 \mathrm{i}$ \\
\hline Hand weeding & $470.8 \mathrm{~d}$ & $441.7 \mathrm{e}$ & $362.5 \mathrm{~h}$ & $9.49 \mathrm{~d}$ & $9.10 \mathrm{e}$ & $5.70 \mathrm{k}$ \\
\hline \multirow[t]{2}{*}{ Weedy check } & $337.5 \mathrm{i}$ & $270.8 \mathrm{j}$ & $204.2 \mathrm{k}$ & $4.32 \mathrm{~m}$ & $3.29 \mathrm{n}$ & $1.94 \mathrm{o}$ \\
\hline & \multicolumn{6}{|c|}{2019 season } \\
\hline Saturn $50 \%$ EC & $454.2 \mathrm{~h}$ & $433.3 \mathrm{j}$ & $354.2 \mathrm{o}$ & $8.80 \mathrm{fg}$ & $8.42 \mathrm{~h}$ & 5.531 \\
\hline Ronstar $25 \%$ EC & $479.2 \mathrm{f}$ & $450.0 \mathrm{~h}$ & $379.2 \mathrm{~m}$ & $8.98 \mathrm{f}$ & $8.70 \mathrm{~g}$ & $5.78 \mathrm{k}$ \\
\hline Saturn $f b$ Granite $24 \%$ SC & $537.5 \mathrm{c}$ & $520.8 \mathrm{~d}$ & $412.5 \mathrm{k}$ & $10.44 \mathrm{c}$ & $10.37 \mathrm{c}$ & $6.97 \mathrm{j}$ \\
\hline Ronstar $f b$ Granite & $566.7 \mathrm{a}$ & $545.8 \mathrm{~b}$ & $441.7 \mathrm{i}$ & $11.02 \mathrm{a}$ & $10.77 \mathrm{~b}$ & $7.75 \mathrm{i}$ \\
\hline Hand weeding & $500.0 \mathrm{e}$ & $462.5 \mathrm{~g}$ & 387.51 & $9.72 \mathrm{~d}$ & $9.30 \mathrm{e}$ & $5.98 \mathrm{k}$ \\
\hline Weedy check & $362.5 \mathrm{n}$ & $329.2 \mathrm{p}$ & $250.0 \mathrm{q}$ & $4.68 \mathrm{~m}$ & $3.63 n$ & $2.19 \mathrm{o}$ \\
\hline
\end{tabular}

Means $f b$ a common letter within a season are not significantly differed at $5 \%$ level, using DMRT

Table (15): Effect of the interaction among irrigation intervals (days), rice cultivars and weed control treatments on rice number of panicles $\mathrm{m}^{-2}$ and rice grain yield $\left(\mathrm{t} \mathrm{ha}^{-1}\right)$ in 2018 and 2019 seasons

\begin{tabular}{|c|c|c|c|c|c|c|c|}
\hline \multirow{2}{*}{$\begin{array}{c}\text { Irrigation } \\
\text { intervals } \\
\text { (days) }\end{array}$} & \multirow{2}{*}{$\begin{array}{c}\text { Rice } \\
\text { cultivars }\end{array}$} & \multicolumn{6}{|c|}{ Weed control treatments } \\
\hline & & Saturn & Ronstar & $\begin{array}{c}\text { Saturn } f b \\
\text { Granite }\end{array}$ & $\begin{array}{c}\text { Ronstar } f b \\
\text { Granite }\end{array}$ & $\begin{array}{c}\text { Hand } \\
\text { weeding }\end{array}$ & $\begin{array}{l}\text { Weedy } \\
\text { check }\end{array}$ \\
\hline & & \multicolumn{6}{|c|}{2018 season } \\
\hline \multirow{2}{*}{3} & Sakha 107 & $425.0 \mathrm{f}-\mathrm{i}$ & $433.3 \mathrm{e}-\mathrm{h}$ & $483.3 \mathrm{~d}$ & $516.7 \mathrm{c}$ & $458.3 \mathrm{e}$ & $308.3 n$ \\
\hline & Giza 179 & 450.0 ef & $441.7 \mathrm{efg}$ & $541.7 \mathrm{~b}$ & $575.0 \mathrm{a}$ & $483.3 \mathrm{~d}$ & 366.71 \\
\hline \multirow{2}{*}{6} & Sakha 107 & $400.0 \mathrm{ijk}$ & $416.7 \mathrm{ghi}$ & $458.3 \mathrm{e}$ & $483.3 \mathrm{~d}$ & $425.0 \mathrm{f}-\mathrm{i}$ & 266.7 op \\
\hline & Giza 179 & $433.3 \mathrm{e}-\mathrm{h}$ & 450.0 ef & $516.7 \mathrm{c}$ & $558.3 \mathrm{ab}$ & $458.3 \mathrm{e}$ & $275.0 \mathrm{o}$ \\
\hline \multirow{3}{*}{9} & Sakha 107 & 375.01 & 375.01 & $408.3 \mathrm{hij}$ & $441.7 \mathrm{efg}$ & $383.3 \mathrm{kl}$ & $250.0 \mathrm{p}$ \\
\hline & Giza 179 & $308.3 \mathrm{n}$ & $325.0 \mathrm{mn}$ & 375.01 & $391.7 \mathrm{jkl}$ & $341.7 \mathrm{~m}$ & $158.3 \mathrm{q}$ \\
\hline & & \multicolumn{6}{|c|}{2019 season } \\
\hline \multirow{2}{*}{3} & Sakha 107 & $441.7 \mathrm{k}$ & $458.3 \mathrm{ij}$ & $500.0 \mathrm{de}$ & $525.0 \mathrm{c}$ & 491.7 ef & $341.7 \mathrm{q}$ \\
\hline & Giza 179 & $466.7 \mathrm{hi}$ & $500.0 \mathrm{de}$ & $575.0 \mathrm{~b}$ & $608.3 \mathrm{a}$ & $508.3 \mathrm{~d}$ & 383.3 no \\
\hline \multirow{2}{*}{6} & Sakha 107 & 416.71 & 425,01 & $475.0 \mathrm{gh}$ & 491.7 ef & $441.7 \mathrm{k}$ & $333.3 \mathrm{qr}$ \\
\hline & Giza 179 & $450.0 \mathrm{jk}$ & $475.0 \mathrm{gh}$ & $566.7 \mathrm{~b}$ & $600.0 \mathrm{a}$ & $483.3 \mathrm{fg}$ & $325.0 \mathrm{rs}$ \\
\hline \multirow{4}{*}{9} & Sakha 107 & 383.3 no & $391.7 \mathrm{mn}$ & 425.01 & $466.7 \mathrm{hi}$ & $400.0 \mathrm{~m}$ & $316.7 \mathrm{~s}$ \\
\hline & Giza 179 & $325.0 \mathrm{rs}$ & $366.7 \mathrm{p}$ & $400.0 \mathrm{~m}$ & 416.71 & $375.0 \mathrm{op}$ & $183.3 \mathrm{t}$ \\
\hline & & \multicolumn{6}{|c|}{ Rice grain yield $\left(\mathrm{t} \mathrm{ha}^{-1}\right)$} \\
\hline & & \multicolumn{6}{|c|}{2018 season } \\
\hline \multirow{2}{*}{3} & Sakha 107 & $7.70 \mathrm{~lm}$ & 7.931 & $9.37 \mathrm{fgh}$ & $9.90 \mathrm{de}$ & $8.80 \mathrm{ij}$ & $4.03 \mathrm{~s}$ \\
\hline & Giza 179 & $9.12 \mathrm{ght}$ & $9.38 \mathrm{fg}$ & $10.91 \mathrm{bc}$ & $11.40 \mathrm{a}$ & $10.19 \mathrm{~d}$ & $4.60 \mathrm{r}$ \\
\hline \multirow{2}{*}{6} & Sakha 107 & $7.39 \mathrm{~m}$ & $7.70 \mathrm{~lm}$ & $9.03 \mathrm{hi}$ & $9.70 \mathrm{ef}$ & $8.57 \mathrm{jk}$ & $3.13 \mathrm{u}$ \\
\hline & Giza 179 & $8.47 \mathrm{k}$ & 9.07 ghi & $10.70 \mathrm{c}$ & $11.20 \mathrm{ab}$ & 9.63 ef & $3.45 \mathrm{t}$ \\
\hline \multirow{3}{*}{9} & Sakha 107 & $5.90 \mathrm{p}$ & 6.03 op & $6.99 n$ & 7.961 & $6.29 \mathrm{o}$ & $2.20 \mathrm{v}$ \\
\hline & Giza 179 & $4.43 \mathrm{r}$ & $4.70 \mathrm{r}$ & $5.87 \mathrm{p}$ & $6.88 \mathrm{n}$ & $5.10 \mathrm{q}$ & $1.68 \mathrm{w}$ \\
\hline & & \multicolumn{6}{|c|}{2019 season } \\
\hline \multirow{2}{*}{3} & Sakha 107 & $8.10 \mathrm{~lm}$ & 8.231 & $9.52 \mathrm{gh}$ & $10.23 \mathrm{de}$ & $9.10 \mathrm{ij}$ & $4.47 \mathrm{t}$ \\
\hline & Giza 179 & $9.51 \mathrm{gh}$ & $9.73 \mathrm{fg}$ & $11.37 \mathrm{bc}$ & $11.81 \mathrm{a}$ & $10.35 \mathrm{~d}$ & $4.90 \mathrm{~s}$ \\
\hline \multirow{2}{*}{6} & Sakha 107 & $7.87 \mathrm{~m}$ & $8.03 \mathrm{~lm}$ & $9.57 \mathrm{gh}$ & 10.00 ef & $8.70 \mathrm{k}$ & $3.52 \mathrm{u}$ \\
\hline & Giza 179 & $8.97 \mathrm{jk}$ & $9.37 \mathrm{hi}$ & $11.17 \mathrm{c}$ & $11.54 \mathrm{ab}$ & $9.89 \mathrm{f}$ & $3.74 \mathrm{u}$ \\
\hline \multirow{2}{*}{9} & Sakha 107 & $6.05 \mathrm{p}$ & $6.35 \mathrm{o}$ & $7.41 \mathrm{n}$ & $8.14 \mathrm{~lm}$ & $6.50 \mathrm{o}$ & $2.51 \mathrm{v}$ \\
\hline & Giza 179 & $5.00 \mathrm{rs}$ & $5.23 \mathrm{qr}$ & $6.53 \mathrm{o}$ & $7.37 \mathrm{n}$ & $5.47 \mathrm{q}$ & $1.87 \mathrm{w}$ \\
\hline
\end{tabular}




\section{Irrigation Water Indicators:}

\subsection{Irrigation water applied (IWA)}

The highest values of irrigation water applied were observed from irrigation interval every 3-days $\left(16127 \mathrm{~m}^{3} \mathrm{ha}^{-1}\right)$, while the lowest values were recorded from irrigation every 9-days $\left(11035 \mathrm{~m}^{3} \mathrm{ha}^{-1}\right)$ as mean of both growing seasons. Irrigation intervals every 6 and 9 days saved irrigation water by $15 \%$ and $31 \%$ compared to 3-days as a mean of the two growing seasons, with increasing irrigation intervals the amount of irrigation water applied decreased. This results are consistent with those obtained by Abd El-Naby and Mahmoud (2018) they found irrigation every six and nine days saved about $21 \%$ and $30 \%$ of irrigation water applied, respectively compared to irrigation every three days. Also, with those obtained by Naresh et al. (2014) and Sriphirom et al. (2019) they found irrigation water applied could be reduced when applying irrigation intervals, alternate wetting and drying (AWD) and intermittent irrigation compared to continuous flooding of rice. Maneepitak et al. (2019) reported that the irrigation water applied was decreased by $29 \%$ under AWD compared to conventional flooding, these results may be due to the reduction of flooded length time and therefore decreases the amount of evaporation Deelstra et al. (2018), seepage Adhya et al. (2014) and percolation Xu et al. (2017). A slight difference of applied irrigation water were observed between different weed control treatments, as well as between the two varieties during both growing seasons as shown in Table (16).

Table (16): The seasonal irrigation water applied $\left(\mathrm{m}^{3} \mathrm{ha}^{-1}\right)$ as related to irrigation intervals, rice cultivars and weed control treatments in 2018 and 2019 seasons

\begin{tabular}{|c|c|c|c|c|c|c|c|}
\hline \multirow{2}{*}{$\begin{array}{c}\text { Irrigation } \\
\text { intervals } \\
\text { (days) }\end{array}$} & \multirow{2}{*}{$\begin{array}{c}\text { Rice } \\
\text { cultivars }\end{array}$} & \multicolumn{6}{|c|}{ Weed control treatments } \\
\hline & & Saturn & Ronstar & $\begin{array}{c}\text { Saturn } f b \\
\text { Granite }\end{array}$ & $\begin{array}{c}\text { Ronstar } \boldsymbol{f b} \\
\text { Granite }\end{array}$ & $\begin{array}{c}\text { Hand } \\
\text { weeding }\end{array}$ & $\begin{array}{l}\text { Weedy } \\
\text { check }\end{array}$ \\
\hline \multicolumn{8}{|c|}{2018 season } \\
\hline \multirow{2}{*}{3} & Sakha 107 & 16280 & 16303 & 16371 & 16309 & 16403 & 16363 \\
\hline & Giza 179 & 16450 & 16355 & 16355 & 16425 & 16492 & 16410 \\
\hline \multirow{2}{*}{6} & Sakha 107 & 13878 & 13899 & 13802 & 13884 & 13921 & 13914 \\
\hline & Giza 179 & 13935 & 13945 & 13850 & 13896 & 13879 & 14034 \\
\hline \multirow{2}{*}{9} & Sakha 107 & 11281 & 11253 & 11329 & 11328 & 11354 & 11273 \\
\hline & Giza 179 & 11337 & 11402 & 11379 & 11356 & 11291 & 11379 \\
\hline \multicolumn{2}{|c|}{ Mean } & 13896 & 13890 & 13866 & 13860 & 13860 & 13848 \\
\hline \multicolumn{2}{|c|}{ Mean } & \multicolumn{2}{|c|}{ 3-days $=16376$} & \multicolumn{2}{|c|}{$6-$ days $=13903$} & \multicolumn{2}{|c|}{$9-$ days $=11330$} \\
\hline & & \multicolumn{3}{|c|}{ Sakha $107=13850$} & \multicolumn{3}{|c|}{ Giza $179=13941$} \\
\hline \multicolumn{8}{|c|}{2019 season } \\
\hline \multirow{2}{*}{3} & Sakha 107 & 15897 & 15887 & 15912 & 15752 & 15797 & 15894 \\
\hline & Giza 179 & 15941 & 15915 & 15978 & 15824 & 15831 & 15892 \\
\hline \multirow{2}{*}{6} & Sakha 107 & 13351 & 13401 & 13392 & 13406 & 13372 & 13354 \\
\hline & Giza 179 & 13375 & 13436 & 13381 & 13428 & 13681 & 13656 \\
\hline \multirow{2}{*}{9} & Sakha 107 & 10664 & 10665 & 10688 & 10711 & 10705 & 10752 \\
\hline & Giza 179 & 10766 & 10769 & 10841 & 10784 & 10746 & 10785 \\
\hline & ean & 13389 & 13365 & 13355 & 13345 & 13332 & 13317 \\
\hline \multirow{2}{*}{\multicolumn{2}{|c|}{ Mean }} & 3-day & 15877 & 6-day & 13436 & 9-day & 0740 \\
\hline & & \multicolumn{3}{|c|}{ Sakha $107=13333$} & \multicolumn{3}{|c|}{ Giza $179=13445$} \\
\hline
\end{tabular}

\subsection{Productivity of irrigation water (PIW):}

As shown in Table (17), irrigation every 6-days recorded the highest values of PIW compared to the other irrigation intervals in the two growing seasons. Irrigation interval every 6-days increased PIW by $13 \%$, compared to 3-days as a mean of the two growing seasons. This result agreed with those obtained by Deelstra et al. (2018) they found the productivity of irrigation water increased from $26 \%$ to $168 \%$ under AWD compared to continuous flooded. This may be due to the reduction of irrigation water applied and higher grain yield production under AWD compared to continuous flooded Deelstra et al. (2018) and
Maneepitak et al. (2019). While, PIW decreased by $9 \%$ under irrigation interval every 9-days compared to 3days, this may be due to grain yield reduction as a result of excessive water stress. Water stress at critical growth stages reduced rice growth, yield and its attributed Maneepitak et al. (2019). Productivity of irrigation water of weed control treatments had the descending order Ronstar $f b$ Granite $>$ Saturn $f b$ Granite $>$ hand weeding $>$ Ronstar $>$ Saturn $>$ weedy check in the two growing seasons. Its increased by $125 \%, 138 \%, 175 \%, 200 \%$ and $150 \%$ for Saturn, Ronstar, Saturn $f b$ Granite, Ronstar $f b$ Granite and hand weeding compared to weedy check as a mean of the two growing seasons. 
Table (17): Influence of irrigation intervals (days), rice cultivars and weed control treatments on productivity of irrigation water $\left(\mathrm{kg} \mathrm{m}^{-3}\right)$ in 2018 and 2019 seasons

\begin{tabular}{|c|c|c|c|c|c|c|c|c|}
\hline \multirow{2}{*}{$\begin{array}{c}\text { Irrigation } \\
\text { intervals } \\
\text { (days) }\end{array}$} & \multirow{2}{*}{$\begin{array}{c}\text { Rice } \\
\text { cultivars }\end{array}$} & \multicolumn{6}{|c|}{ Weed control treatments } & \multirow[b]{2}{*}{ Mean } \\
\hline & & Saturn & Ronstar & $\begin{array}{l}\text { Saturn } f b \\
\text { Granite }\end{array}$ & $\begin{array}{c}\text { Ronstar } \\
\text { fb Granite }\end{array}$ & $\begin{array}{c}\text { Hand } \\
\text { weeding }\end{array}$ & $\begin{array}{l}\text { Weedy } \\
\text { check }\end{array}$ & \\
\hline \multicolumn{9}{|c|}{2018 season } \\
\hline \multirow[b]{2}{*}{3} & Sakha 107 & $0.47 \mathrm{ij}$ & $0.49 \mathrm{i}$ & $0.57 \mathrm{f}$ & $0.61 \mathrm{e}$ & $0.54 \mathrm{gh}$ & $0.25 \mathrm{~m}$ & $0.49 \mathrm{e}$ \\
\hline & Giza 179 & $0.55 \mathrm{fg}$ & $0.57 \mathrm{f}$ & $0.67 \mathrm{~d}$ & $0.69 \mathrm{c}$ & $0.62 \mathrm{e}$ & 0.281 & $\begin{array}{c}0.56 \\
b\end{array}$ \\
\hline \multirow{2}{*}{6} & Sakha 107 & $0.53 \mathrm{gh}$ & $0.55 \mathrm{fg}$ & $0.65 \mathrm{~d}$ & $0.70 \mathrm{c}$ & $0.62 \mathrm{e}$ & $0.23 \mathrm{~m}$ & $0.55 \mathrm{c}$ \\
\hline & Giza 179 & $0.61 \mathrm{e}$ & $0.65 \mathrm{~d}$ & $0.77 \mathrm{~b}$ & $0.80 \mathrm{a}$ & $0.70 \mathrm{c}$ & $0.24 \mathrm{~m}$ & $0.63 \mathrm{a}$ \\
\hline \multirow{2}{*}{9} & Sakha 107 & $0.52 \mathrm{~h}$ & $0.54 \mathrm{gh}$ & $0.61 \mathrm{e}$ & $0.70 \mathrm{c}$ & $0.55 \mathrm{fg}$ & $0.20 \mathrm{n}$ & $\begin{array}{c}0.52 \\
\mathrm{~d}\end{array}$ \\
\hline & Giza 179 & $0.39 \mathrm{k}$ & $0.41 \mathrm{k}$ & $0.51 \mathrm{~h}$ & $0.61 \mathrm{e}$ & $0.45 \mathrm{j}$ & $0.15 \mathrm{o}$ & $0.40 \mathrm{f}$ \\
\hline \multicolumn{2}{|c|}{ Mean } & $0.51 \mathrm{e}$ & $0.54 \mathrm{~d}$ & $0.63 \mathrm{~b}$ & $0.69 \mathrm{a}$ & $0.58 \mathrm{c}$ & $0.23 \mathrm{f}$ & \\
\hline \multicolumn{2}{|c|}{ Mean } & \multicolumn{2}{|c|}{ 3-days $=0.53 \mathrm{~b}$} & \multicolumn{2}{|c|}{ 6-days $=0.59$ a } & \multicolumn{2}{|c|}{ 9-days $=0.46 \mathrm{c}$} & \\
\hline & & \multicolumn{3}{|c|}{ Sakha $107=0.52 \mathrm{~b}$} & \multicolumn{3}{|c|}{ Giza $179=0.53$ a } & \\
\hline \multicolumn{9}{|c|}{2019 season } \\
\hline \multirow[b]{2}{*}{3} & Sakha 107 & $0.51 \mathrm{mn}$ & $0.52 \mathrm{~m}$ & $0.60 \mathrm{jk}$ & $0.65 \mathrm{i}$ & $0.58 \mathrm{jk}$ & $0.28 \mathrm{q}$ & $0.52 \mathrm{e}$ \\
\hline & Giza 179 & $0.60 \mathrm{jk}$ & $0.61 \mathrm{j}$ & 0.71 ef & $0.75 \mathrm{~cd}$ & $0.66 \mathrm{i}$ & $0.31 \mathrm{p}$ & $\begin{array}{c}0.61 \\
b\end{array}$ \\
\hline \multirow{2}{*}{6} & Sakha 107 & $0.59 \mathrm{jkl}$ & $0.60 \mathrm{jk}$ & $0.72 \mathrm{ef}$ & $0.75 \mathrm{~cd}$ & $0.65 \mathrm{i}$ & $0.26 \mathrm{q}$ & $0.60 \mathrm{c}$ \\
\hline & Giza 179 & $0.67 \mathrm{hi}$ & $0.70 \mathrm{fg}$ & $0.83 \mathrm{~b}$ & $0.86 \mathrm{a}$ & $0.73 \mathrm{de}$ & $0.27 \mathrm{q}$ & $0.68 \mathrm{a}$ \\
\hline \multirow{2}{*}{9} & Sakha 107 & 0.571 & $0.60 \mathrm{jk}$ & $0.70 \mathrm{fgh}$ & $0.76 \mathrm{c}$ & $0.61 \mathrm{j}$ & $0.23 \mathrm{r}$ & $\begin{array}{c}0.58 \\
d\end{array}$ \\
\hline & Giza 179 & $0.46 \mathrm{o}$ & 0.48 no & $0.60 \mathrm{jk}$ & $0.68 \mathrm{gh}$ & $0.51 \mathrm{mn}$ & $0.17 \mathrm{~s}$ & $0.48 \mathrm{f}$ \\
\hline \multicolumn{2}{|c|}{ Mean } & $0.57 \mathrm{e}$ & $0.59 \mathrm{~d}$ & $0.69 \mathrm{~b}$ & $0.74 \mathrm{a}$ & $0.62 \mathrm{c}$ & $0.25 \mathrm{f}$ & \\
\hline \multicolumn{2}{|c|}{ Mean } & \multicolumn{2}{|c|}{3 -days $=0.57 \mathrm{~b}$} & \multicolumn{2}{|c|}{ 6-days $=0.64 \mathrm{a}$} & \multicolumn{2}{|c|}{9 -days $=0.53 \mathrm{c}$} & \\
\hline & & \multicolumn{3}{|c|}{ Sakha $107=0.57 \mathrm{~b}$} & \multicolumn{3}{|c|}{ Giza $179=0.59$ a } & \\
\hline
\end{tabular}

The interaction between irrigation intervals, rice cultivars and weed control treatments showed significant differences in PIW between all interactions in the two growing seasons. The highest values of PIW resulted from irrigation interval every 6-days with Giza 179 treated by Ronstar $f b$ Granite at recommended doses followed by the same irrigation interval and rice cultivar under Saturn $f b$ Granite at recommended doses in the two growing seasons. It increased after these two interactions by $69 \%$ and $63 \%$ respectively compared to irrigation every 3-days with Sakha 107 treated by Saturn at recommended dose (traditional practices by farmers) also, it increased after the same two interactions by $214 \%$ and $202 \%$ respectively compared to irrigation every 3-days with Sakha 107 under weedy check as a mean of the two growing seasons. While, the lowest values of PIW resulted from irrigation every 9-days with Sakha 107 under weedy check as well as 9-days with Giza 179 under weedy check to be 0.22 and $0.16 \mathrm{~kg} \mathrm{~m}^{-1}$ as mean during two growing seasons. The increases in PIW values may be due to the enhancement of growth characters, photosynthetic activity and provide adequate nutrition for rice crop plants which play a major role in the efficient use and conservation of water resources. PIW determines the capability of the plants to convert the water applied to yield. The increases in PIW was mainly related to the role of weed control and irrigation intervals to promote and support rice growth which was the result of raising photosynthesis assimilation in building metabolites and consequently yield is enhanced (Abd El-Naby and Mahmoud (2018).

\section{CONCLUSION}

Due the limitations of water resources in Egypt and the high abundance of weed in rice fields, from this study it could be concluded that, the best weed control, rice growth, yield and its attributes as well as productivity of irrigation water $\left(0.83 \mathrm{~kg} \mathrm{~m}^{-3}\right)$ were obtained from irrigation every 6-days with Giza $179 \mathrm{cv}$ treated by Ronstar $\left(1.79 \mathrm{~L} \mathrm{ha}^{-1}\right)$ at 4 DAT $f b$ Granite $\left(83.3 \mathrm{ml} \mathrm{ha}^{-1}\right)$ at $20 \mathrm{DAT}$. In case of severe water shortage (irrigation every 9-days) with Sakha $107 \mathrm{cv}$ treated by Ronstar $f b$ Granite at recommended doses achieved the best weed control, rice growth, a reasonable yield and its attributes as well as productivity of irrigation water $\left(0.73 \mathrm{~kg} \mathrm{~m}^{-3}\right)$, moreover saved $31 \%$ from irrigation water during two growing seasons compared to traditional farmer practices. 


\section{REFERENCES}

Abbasi, M. R. and A. R. Sepaskhah (2011). Effects of water-saving irrigations on different rice cultivars (Oryza sativa L.) in field conditions. International J. Plant Prod., 5(2): 153-166.

Abd El-Naby, S. S. M. and M. A. Mahmoud (2018). Enhancing irrigation water productivity of rice using irrigation intervals, transplanting methods and weed control in North Nile Delta J. Soil Sci. and Agric. Eng., Mansoura Univ., 9(1): 11- 20.

Abd El-Naby, S. S. M., Abou El-Darag, I. H. and A. M. A. El-Ghandor (2017). Weed management in broadcast-seeded hybrid rice (Oryza sativa L.). J. Plant Prod., Mansoura Univ., 8(10): 1021-1028.

Abou El-Darag, I. H., S. S. M. Abd El-Naby and A. M. A. El-Ghandor (2017). Effect of water regime and weed control treatments on weeds, growth and yields in hybrid rice. J. Plant Prod., Mansoura Univ., 8(9): 939-943.

Abou El-Hassan, W. H., Y. Kitamura, K. Hasegawa, S. L. Yang and H. Solomon (2006). Water management using drainage water and its impact on irrigated rice in the Delta region of Egypt. Eight ${ }^{\mathrm{h}}$ International Conference on Dry land Development, 25-28 February, Beijing, China.

Adhya, T. K., B. Linquist, T. Searchinger, R. Wassmann and X. Yan (2014). Wetting and drying: reducing greenhouse gas emissions and saving water from rice production. World Resources Institute, Washington, DC.

Alhaj, Y., X. Guo, Z. Wang, H. Shaghaleh, S. Chen, A. Hassan and A. Bakour (2019). Effects of irrigation regime and soil clay content and their interaction on the biological yield, nitrogen uptake and nitrogen-use efficiency of rice grown in southern China. Agric. Water Manag., 213: 934-946.

Ali, M. H., M. R. Hoque, A. A. Hassan and A. Khair (2007). Effects of deficit irrigation on yield, water productivity and economic returns of wheat. Agric. water Manag., 92: 151-161.

Anwar, M. P., A. S. Juraimi, M. Azmi, P. Adam, A. Selamat and B. Mahfuza (2010). Weed suppressive ability of rice (Oryza sativa L.) germplasm under aerobic soil conditions. Aust. J. Crop Sci., 4(9): 706-717.

Bajavathiannan, M. V., J. K. Norsuorthy and R. C. Scott (2011). Comparison of weed management programs for furrow-irrigated and flooded hybrid rice production in Arkansas. Weed Technology, 25(4): 556-562.

Bozorgi, H. R., F. Tarighi, M. Moradi and E. Azarpour (2011). The study effect of drought stress on four native rice varieties in Iran. World Appl. Sci. J., 13(3): 410-414.

Deelstra, J., U. S. Nagothu, K. R. Kakumanu, Y. R. Kaluvai and S. R. Kallam (2018). Enhancing water productivity using alternative rice growing practices: A case study from Southern India. J. Agric. Sci., 156: 673-679.
Drost, D. C. and K. Moody (1982). Effect of butachlor on Echinichloa glubrescensin wet seeded rice (Oryza sativa L.). Philippines J. Weed Sci., 9: 44-57.

Duncan, D. B. (1955). Multiple range and multiple Ftests. Biometrics, 11: 1-42.

El-Namaky, A. M. M. (2007). Genetic studies on using wide compatibility gene in hybrid rice breeding Ph.D. Thesis. Genetic Dep. Fac. of Agric. Mansora Univ. Egypt.

FAOSTAT (2017). FAO Statistical databases. Food and Agriculture Organization (FAO) of the United Nations, Rome. www.fao.org.

Galwash, A. M., E. A. Abo-Marzoka and T. Ismail (2018). Effect of rice cultivars and herbicidal combinations integrations on weeds and yield of broadcast-seeded rice productivity and economic feasibility. J. plant production, Mansoura Univ., 9(12): 1231-1242.

Gealy, D. R., M. Anders, B. Watkins and S. Duke (2014). Crop performance and weed suppression by weed-suppressive rice cultivars in furrow- and flood-irrigated systems under reduced herbicide inputs. Weed Sci., 62: 303-320.

Hassan, Md. N., S. Ahmed, Md. J. Uddin and Md. M. Hassan (2010). Effect of weeding regime and planting density on morphology and yield attrbiutes of transplant aman rice cv. Brridhan 41. Pak. J. Weeds Sci. Res., 16(4): 363-377.

Islam, S. M. M., S. K. Paul and M. A. R. Sakar (2015). Effect of weeding regime and integrated nutrient management on yield contributing characters and yield of BRRI dhan 49. J. of Crop and Weed, 11: 193-197.

Kar, I., S. Yadav, A. Mishra, B. Behera, C. Khanda, V. Kumar and A. Kumar (2017). Productivity trade-off with different water regimes and genotypes of rice under non-puddled conditions in Eastern India. F. Crop. Res. In Press.

Kato, Y., A. Kamoshita and J. Yamagishi (2006). Growth of three rice (Oryza sativa L.) cultivars under upland conditions with different levels of water supply. II. Grain yield. Plant Prod. Sci., 9(4): 435-445.

Klute, A. (1986). Methods of soil analy-sis, part 1: physical and Miner-alogical methods $\left(2^{\text {nd }}\right) \mathrm{Ed}$ American Soci. of Agronomy, Madison, Wisconsin, USA.

Kumar, A., A. K. Nayak, D. R. Pani and B. S. Das (2017). Physiological and morphological responses of four different rice cultivars to soil water potential based deficit irrigation management strategies. F. Crop. Res., 205: 78-94.

Liang, K., X. Zhong, N. Huang, R. M. Lampayan, J. Pan, K. Tian and Y. Liu (2016). Grain yield, water productivity and $\mathrm{CH}_{4}$ emission of irrigated rice in response to water management in south China. Agric. Water Manag., 163: 319-331. 
Mahmoud, M. (2015). Yield and water productivity of rice on raised beds, irrigation intervals and ammonia gas injection at North Nile Delta. J. Soil Sci. Agric. Eng., Mansoura Univ., 6: 1373-1387.

Majumdar, D. K. (2002). Irrigation water management: Principles and Practice. $2^{\text {nd }}$ ed. Prentice Hall of India, New Delhi, 110001, 487p.

Maneepitak, S., H. Ullah, K. Paothong, B. Kachenchart, A. Datta and R. P. Shrestha (2019). Effect of water and rice straw management practices on yield and water productivity of irrigated lowland rice in the Central Plain of Thailand. Agric. Water Manag., 211: 89-97.

Manhanas, S.S.; G. Singh; D. Singh and V. Khajuria (2012). Effect of tank-mixed herbicides on weeds and transplanted rice (Oryza sativa L.) Ann. Agric. Res. News Series, 33(1\&2):2531.

Munda, S., S. Saha, T. Adak and N. Jambhulkar (2017). Weed management in aerobic rice: Role of establishment methods and herbicides. Expl. Agric. page 1 of 17.

Naresh, R. K., S. S. Tomar, D. Kumar, S. P. Singh, A. Dwivedi, V. Kumar and others (2014). Experiences with rice grown on permanent raised beds: Effect of crop establishment techniques on water use, productivity, profitability and soil physical properties. Rice Sci., 21: 170-180.

Norton, G. J., M. Shafaei, A. J. Travis, C. M. Deacon, J. Danku, D. Pond, N. Cochrane and others (2017). Impact of alternate wetting and drying on rice physiology, grain production and grain quality. F. Crop. Res., 205: 1-13.

Page, A. L., R. H. Miller and D. R. Keeney (1982). Methods of soil analysis-chemical and microbiological properties. Madison, Wisconsin. s. (Table 1).
Paramita, B., D. Dutta, S. Biswas, P. Bandyoopadhay and D. Maiti (2005). Effect of irrigation and weed management on weed growth and yield performance of transplanted hybrid rice. J. Crop and weed, 2(1): 20-22.

Ramana, A. V., D. S. Reddy and K. Ramakumar (2014). Influence of sowing time and nitrogen level on growth, yield and $n$ uptake of rainfed upland rice varieties. The Andhra agric. J., 54(3\&4): 114-120.

Romeo, C., E. Phuc, L. Castillo, G. Guoan, B. Yuanlai and C. J. Yuanhua (2004). Effect of irrigation method and $\mathrm{N}$-fertilizer management on rice yield, water productivity and nutrient- use efficiencies in typical lowland rice conditions in China, Paddy Water Environ. 2:195-206.

Sarkar, Md. A. R., S. K. Paul and U. Paul (2017). Effect of water and weed management in Boro rice (cv. BRRI dhan 28) in Bangladesh. Archives of Agric. and Environ. Sci., 2(4): 325-329.

Shebl, S. M. I. H. Abou El-Darag and H. F. El-Mwafi (2009). Effects of varietal performance and weed control efficacy on weeds, growth and yield of hybrid rice. J. Agric. Res. Kafr ElSheikh Univ., 35(1): 127-147.

Snedecor, G. W. and W. G. Cochran. (1971). Statistical Methods. $6^{\text {th }}$ ed. Iowa State Univ. Press Amer, USA.

Sriphirom, P., A. Chidthaisong and S. Towprayoon (2019). Effect of alternate wetting and drying water management on rice cultivation with low emissions and low water used during wet and dry season. J. Clean. Prod., 223: 980-988.

Xu, B., D. Shao, X. Tan, X. Yang, W. Gu and H. Li (2017). Evaluation of soil water percolation under different irrigation practices, antecedent moisture and groundwater depths in paddy fields. Agric. Water Manag., 192: 149-158. 


\section{التأثير المتبادل لفترات الري ومكافحة الحشائش لتحسين المحصول وإنتاجيه مياه الري لصنفين من الأرز

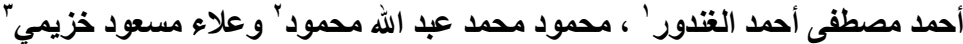

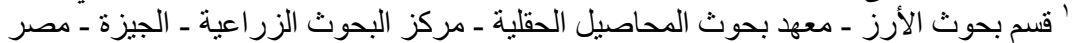

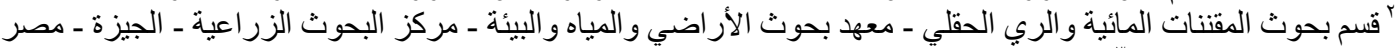

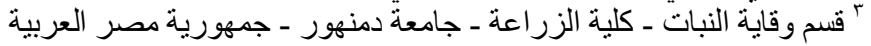

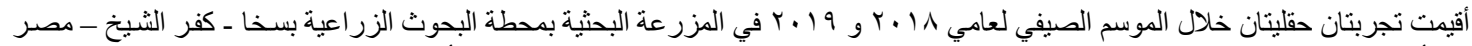

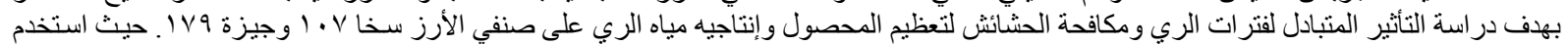

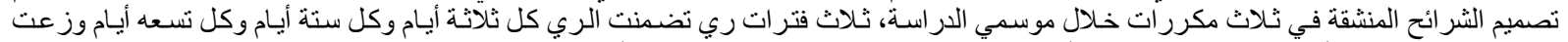

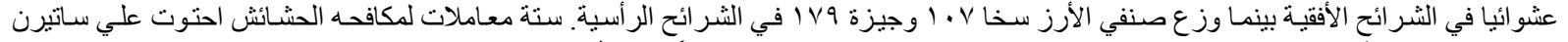

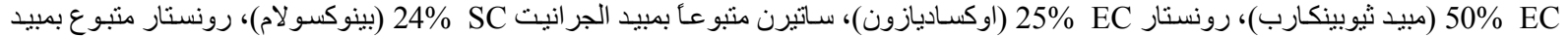

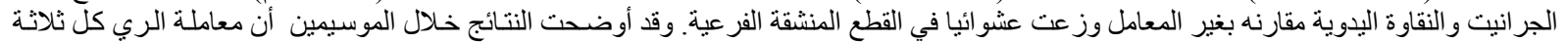

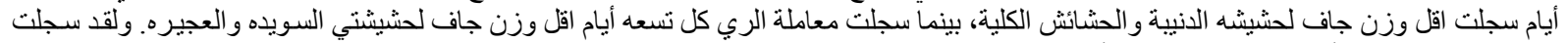

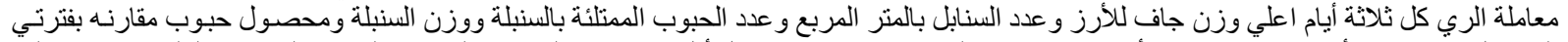

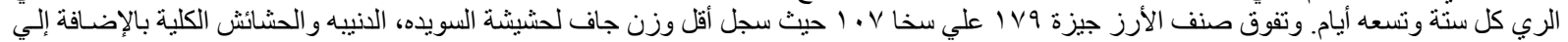

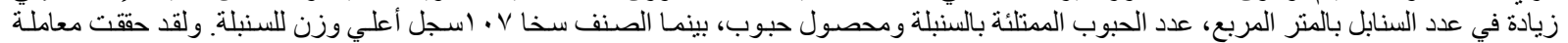

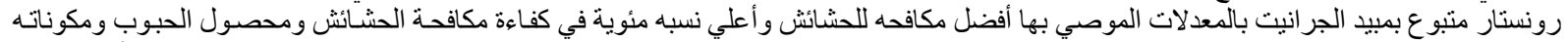

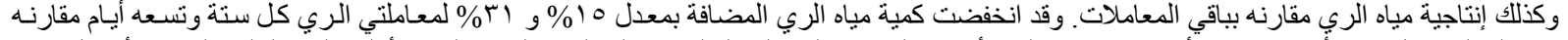

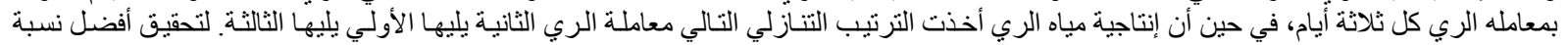

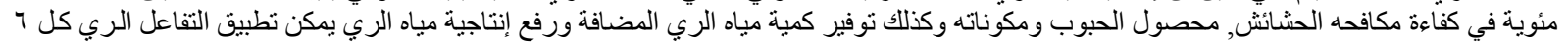

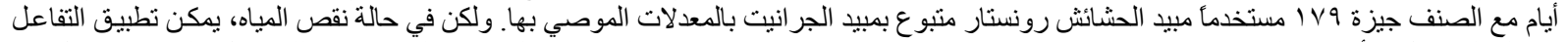

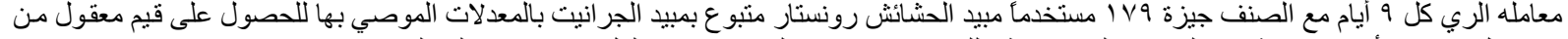

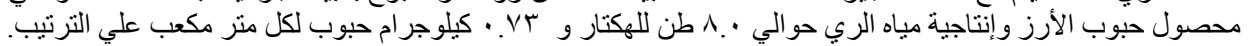

